\title{
Ontwikkeling van differensiële aandrywing met haptiese gebruikersterugvoer
}

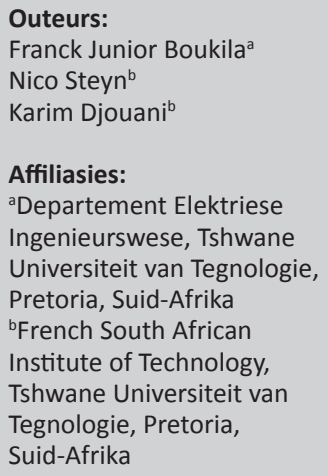

Hierdie artikel handel oor die modellering van 'n bewegingsplatform met twee grade van vryheid wat in 'n geougmenteerderealiteit-omgewing vir handgedrewe mobiliteithulpmiddels aangewend kan word. Die geougmenteerde bewegingsplatform dien as ' $n$ evaluerings- of rehabilitasiehulpmiddel vir gebruikers met 'n gestremde onderste ledemaat en die handgedrewe mobiliteitshulpmiddel wat hulle gebruik. Hierdie handgedrewe mobiliteitshulpmiddel kan gesien word as 'n konvensionele handgedrewe rolstoel wat differensieel aangedryf word. Die twee grade van vryheid wat met die bewegingsplatform geassosieer word, skep geougmenteerderealiteit-navigasie in ' $n$ denkbeeldige omgewing. Die twee grade van vryheid wat met geougmenteerderealiteit-navigasie verband hou, laat die gebruiker in 'n denkbeeldige omgewing vooruitbeweeg terwyl hapties-dinamiese terugvoer ervaar word. Die geproduseerde hapties-dinamiese terugvoer vanaf die geougmenteerde navigasie is die gevolg van gesimuleerde gravitasiekrag en traagheidskragte soos dit in die werklikheid deur'n gebruiker van 'n handgedrewe rolstoel ervaar sou word. Uit die bostaande is dit duidelik dat dit nodig is om behoorlike dinamiese modelle van handgedrewe rolstoele en die gebruikers daarvan op die bewegingsplatform met twee grade van vryheid te ontwikkel en te implementeer om 'n doeltreffende geougmenteerde hapties gesimuleerde omgewing te skep.

Sleutelwoorde: handgedrewe mobiliteitshulpmiddels, geougmenteerde realiteit, haptiese terugvoer, denkbeeldige omgewing

\section{Afkortings}

ADL: Aktiwiteit in daaglikse lewe

ARS: Aandrywing met reëlbare spoed

GR: Geougmenteerde realiteit

GV: Gesigsveld

GVV: Grade van vryheid

HIU: Herkonfigureerde inset-uitset

KGS: Kopgemonteerde skerm

LKR: Lineêre kwadratiese reguleerder

NI: $\quad$ National Instruments

PIA: Proporsionele integraalafgeleide

SP: $\quad$ Massamiddelpunt

VR: Virtuele realiteit

Development of a User Haptic Feedback Differential Drive: This paper concerns the modelling of a two degrees of freedom motion platform that may be employed in an augmented reality environment for manual mobility aids. The augmented motion platform serves as an evaluation or rehabilitation tool for a lower limb disabled user with their associated manual mobility aid. This manual mobility aid may be seen as a conventional manual wheelchair with a manual propelled differential drive action. The two degrees of freedom associated with the motion platform creates an augmented navigation in a fictitious environment. The two degrees of freedom related to augmented navigation lets the user progress in a fictitious environment and experience haptic dynamic feedback. The produced haptic feedback on the augmented navigation is due to a simulated gravitational force and inertial forces to be experienced by a manual wheelchair user as in reality. It is evident from the above that proper dynamic models of the manual wheelchair and its user on the two degrees of freedom motion platform need to be developed and implemented to create an effective augmented haptic simulated environment.

Keywords: Manual mobility aids, Augmented reality, Haptic feedback, Fictitious environment 


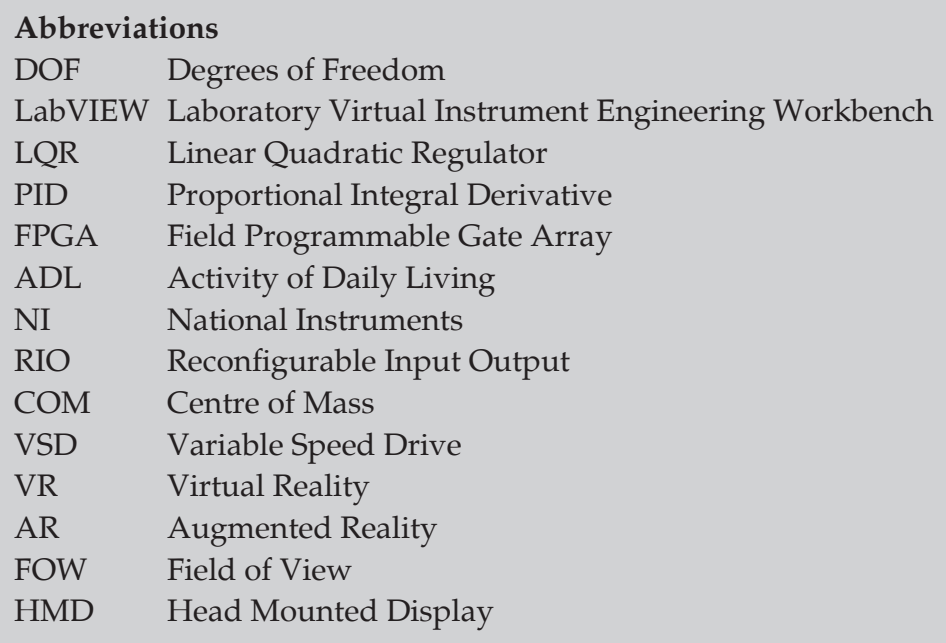

\section{Inleiding}

Die studie wat hier weergegee word, bestaan uit 'n bewegingsimulator met ' $n$ haptiese koppelvlak om 'n gestremde individu toe te laat om bewegingsensasies te ervaar terwyl hulle in ' $n$ denkbeeldige omgewing in navigeer. Boonop kan hulle op die trajek besluit deur die rolstoelwiele te beweeg asof hulle oor 'n werklike plat oppervlak beweeg.

Daar is verskillende moontlike metodes om visuele grafiese inhoud op 'n virtuele simulatorplatform aan die gebruiker oor te dra, waarvan die belangrikste faktor is dat virtuele wêrelde byna intyds aan die gebruiker oorgedra moet word. Die verskillende tipes grafiese koppelvlakke kan in drie algemene tipes verdeel word: meervuldige skerms, hemisferiese skerms en kopgemonteerde skerms (KGS) (Steyn et al. 2014).
Die bewegingsplatformstelsel wat ontwerp is, bestaan uit vier plasmaskerms wat as 'n gebruiker se visuele koppelvlak gebruik kan word (Figuur 1), hoewel 'n KGS saam met 'n giroskopiese spoortoestel gebruik kan word (Steyn et al. 2014). Vier plasmaskerms word gebruik om die gesigsveld (GV) só uit te brei dat dit die gebruiker se voorgrondbeeld insluit.

Hierdie artikel bespreek die gebruiker, die handgedrewe rolstoel en die omgewingskoppelvlak van die bewegingsplatform. Die platform wat hier geillustreer word (Figuur 1), word deur twee aktueerders geaktueer om die hoekbeweging van die gebruiker se handgedrewe rolstoel volgens die gebruikersposisie in 'n denkbeeldige omgewing te simuleer. Hierdie denkbeeldige omgewing verteenwoordig die virtuele argitektoniese omgewing waardeur

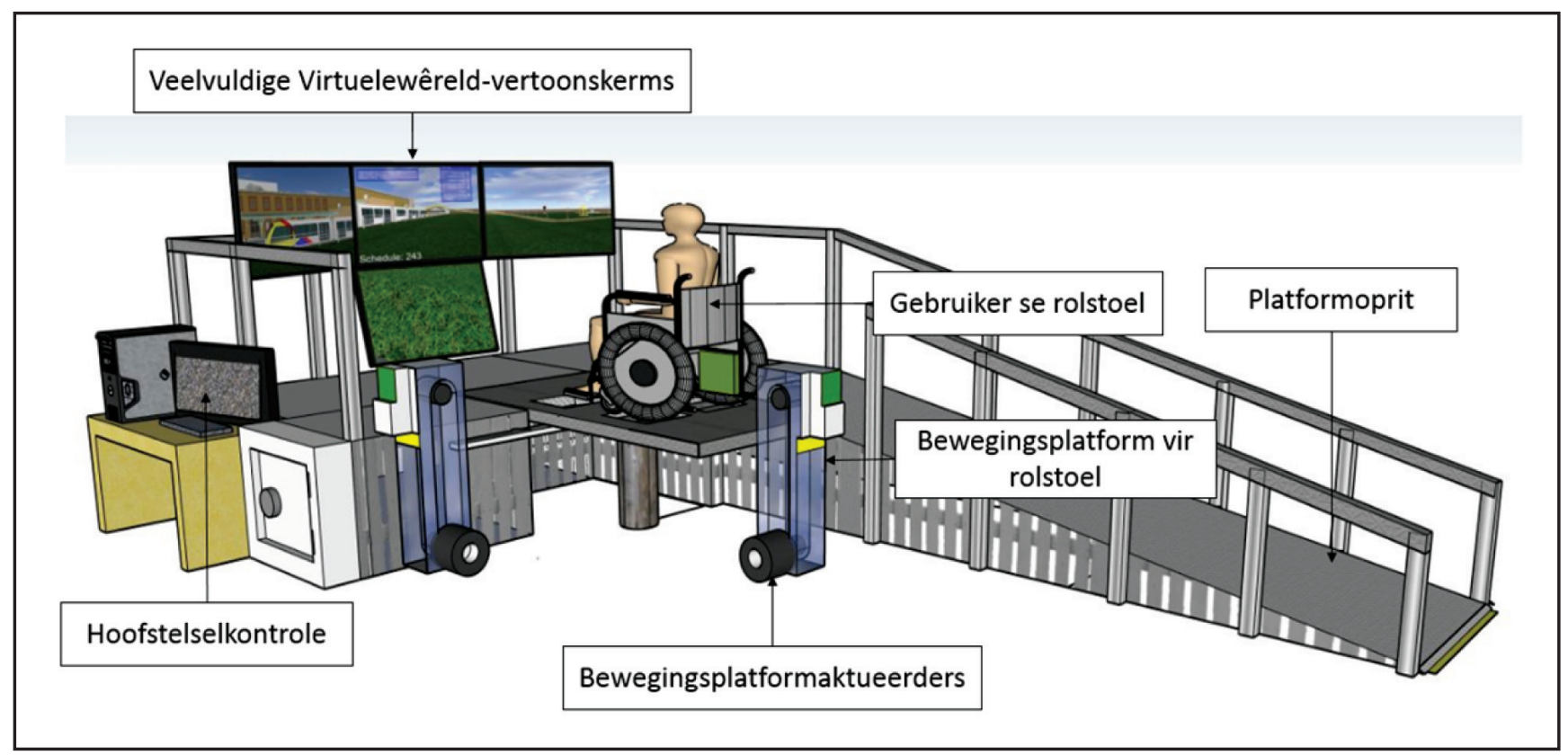

FIGUUR 1: Geheeluitbeelding van stelsel se koppelvlak met gesigsveld (GV) 
die gebruiker sal navigeer. Die rollers en enkodeerders (sensors) is op die bewegingsplatform gemonteer om snelheidsterugvoer vanaf albei wiele van die handgedrewe rolstoel te meet wanneer die gebruiker 'n dryfaksie op die wiele uitoefen terwyl die gebruiker deur 'n koppelvlak met die virtuele argitektoniese omgewing gekoppel is. Hierdie implementering van die bewegingsplatformsimulator sal moontlik gemaak word deur'n kontroleontwerpkoppelvlak te ontwikkel, soos in hierdie artikel bespreek word.

\section{Differensiëleaandrywing-simulator Differensiële aandrywing van handgedrewe rolstoel}

Die differensiële aandryfwiele maak dit vir die rolstoel moontlik om met gemak oor oop oppervlakke te navigeer. Indien $\omega_{L}$ en $\omega_{R}$ die hoeksnelhede van die linker- en regteraandryfwiele verteenwoordig, kan vorentoebewegingsomskakeling bewerkstellig word indien $\omega_{L}=\omega_{R^{\prime}}$ terwyl trubewegingsomskakeling bewerkstellig kan word indien $-\omega_{\mathrm{L}}=-\omega_{\mathrm{R}}$. Rotasie van die rolstoel word bewerkstellig indien $\omega_{\mathrm{L}}<\omega_{\mathrm{R}}$ of $\omega_{\mathrm{L}}>\omega_{\mathrm{R}}$. Die rolstoel kan om die middelpunt van die twee aandryfwiele $\left(\mathrm{c}_{\omega}\right)$ relatief tot die grond roteer indien $+\omega_{\mathrm{L}}=-\omega_{\mathrm{R}}$ of $-\omega_{\mathrm{L}}=+\omega_{\mathrm{R}}$, of aan 'n volledige rolstoelrotasieaksie. Die middelpunt van die rolstoel, bepaal deur de middelpunt van die twee aandryfwiele, word aangedui deur $\left(c_{g}\right)$. 'n Verdere moontlike rolstoelrotasie kom voor indien die rolstoel om die vertikale grondkontakpunt van 'n stilstaande wiel roteer, met een aandryfwiel wat geaktueer word $\omega_{L}>0$ en $\omega_{R}=0$ of $\omega_{R}>$ en $\omega_{\mathrm{L}}=0$ (Steyn et al. 2014).

'n Uitbeelding van die rolstoel se linker- en regterwielsnelhede, met 'n gevolglike boaansig-rolstoelraamrotasie, word in Figuur 2 weergegee. In die modellering van die rolstoel se dinamiese response word die middelpuntlineêre snelheid $\left(V_{c \omega}\right)$ en middelpunt-rotasiesnelheid $\left(\omega_{c \omega}\right)$ in 'n globale verwysingsraamwerk gebruik.

Die rolstoel se middelpunt- lineêre snelheid in 'n globale verwysingsraamwerk vanaf die twee differensieel aangedrewe dryfwiele word deur die volgende vergelyking weergegee (Steyn et al. 2014):

$$
\mathrm{V}_{\mathrm{c} \omega}=\frac{1}{2}\left(\mathrm{~V}_{\mathrm{L}}+\mathrm{V}_{\mathrm{R}}\right)
$$

Die rotasiesnelheid $\left(\omega_{c \omega}\right)$ van die rolstoel kan bereken word as die wiel oombliklik langs die boog van 'n sirkel met 'n radius van $\lambda_{\mathrm{s}}$ (die lengte van die dryfas) beweeg:

$$
\omega_{c \omega}=\frac{1}{\lambda_{s}}\left(V_{L}+V_{R}\right)
$$

Die rolstoel se kinematiese beweging, relatief tot die plaaslike verwysingsraamwerk daarvan, kan dan soos volg bepaal word (Steyn et al. 2014):

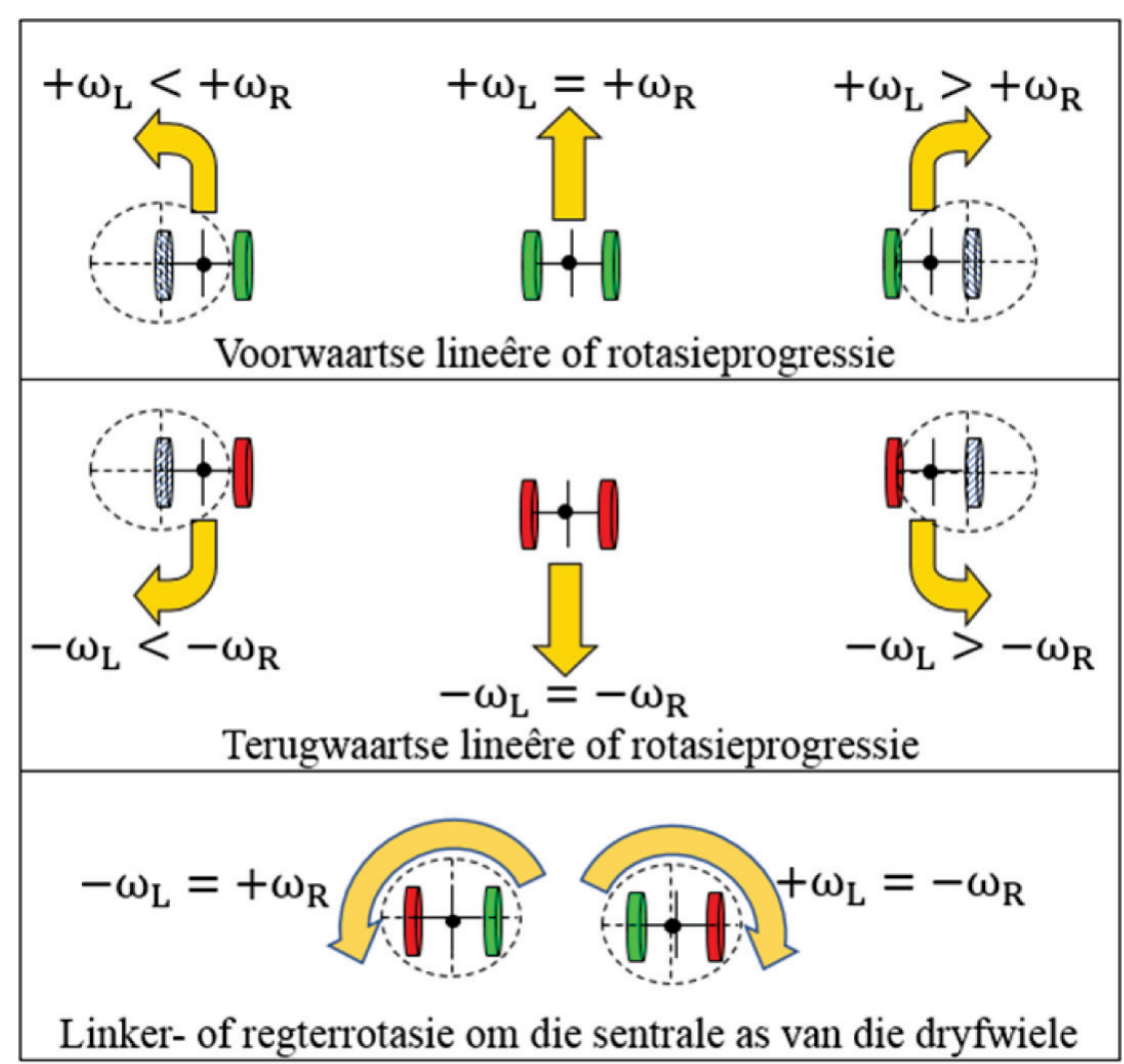

FIGUUR 2: Boaansig-uitbeelding van die differensiëleaandrywing-konfigurasie 


$$
\left[\begin{array}{c}
\dot{x} \\
\dot{y} \\
\dot{\psi}
\end{array}\right]=\left[\begin{array}{ccc}
\cos \psi & -\sin \psi & 0 \\
\sin \psi & \cos \psi & 0 \\
0 & 0 & 1
\end{array}\right]\left[\begin{array}{c}
\mathrm{V}_{\mathrm{cw}} \\
0 \\
\omega_{\mathrm{cw}}
\end{array}\right]
$$

waar $\dot{x}$ en y die nuwe rolstoelsnelheid relatief tot ' $n$ globale verwysingsraamwerk verteenwoordig, en $\dot{\psi}$ die rolstoel se kantelafwykingshoek of rotasiehoek verteenwoordig. Die kinematiese model kan inligting voorsien oor die beweging van die rolstoel, gegewe die komponent van die differensieel aangedrewe wielspoed (Siegwart en Nourbakhsh 2004).

Die dryfaksie van die gebruiker laat die bewegingsplatform 'n snelheid ervaar wat ooreenstem met die snelhede van die rolstoel-aandryfwiele. Hierdie rollersnelhede word na die platformreguleerder oorgedra om die toepaslike aktueerder se op- en af- of kantelreaksies te kies. Die bewegingsterugvoer produseer haptiese insette aan die gebruiker in 'n geougmenteerderealiteit-omgewing. Hierdie bewegingsterugvoer is ' $n$ beduidende element in die evaluering van die gebruiker se reaksies op sekere trajekte of om die werkverrigting van die gebruiker in 'n geougmenteerderealiteit-omgewing vergeleke met die werklike omgewing te evalueer (Steyn et al. 2014).

Op grond van die beskrywing van die dinamiese respons van 'n rolstoel is dit noodsaaklik om 'n assestelsel te definieer om as verwysing vir die definiëring van die verskillende parameters te dien.

Figuur 3 beeld 'n gebruiker uit op 'n handgedrewe rolstoel in 'n asstelsel en die verbandhoudende afmetings. Dit is ontwerp om verskillende parameters te verteenwoordig.

Dryfkrag wat met 'n rolstoel verband hou, bestaan uit twee onafhanklike kragte wat deur die linker- en regteraandryfwiele van 'n rolstoel geproduseer word. Op 'n enkele wiel lewer ' $n$ wringkrag rondom die rotasie-as van die wiel 'n krag om die rolstoel te versnel, terwyl 'n remwringkrag 'n krag lewer om dit te vertraag. Om die dinamiese vergelykings in die beskrywing van die wielkragte by grondkontak te bepaal, is dit nodig om die gekombineerde rolstoel- en gebruikersmassa $\left(m_{c g}\right)$ by die swaartemiddelpunt van die rolstoel vas te stel. Dit beskryf dan die gesamentlike massas van die rolstoel en gebruiker as 'n enkele, starre liggaam. Die rolstoel se middelpuntlineêre versnelling $\left(\mathrm{a}_{\mathrm{cw}}\right)$ en gevolglike rotasieversnelling $\left(\alpha_{\mathrm{cw}}\right)$ as gevolg van die kragte wat geproduseer word, is noodsaaklik om die dinamiese eienskappe te definieer. ' $n$ Verdere komponent, as gevolg van 'n hellende trajek, sal ingebring word om 'n op- of afwaartse hoek $(\theta)$ van die starre liggaam voor te stel (Steyn et al. 2014).

Volgens Vergelyking 1 en 2 kan die rolstoel se middellynlineêre en rotasiesnelheid en versnelling bereken word indien die veranderlike snelhede van die linkerwiel $\left(\mathrm{V}_{\mathrm{L}}\right)$ en die regterwiel $\left(\mathrm{V}_{\mathrm{R}}\right)$ bekend is:

$$
\begin{aligned}
& a_{\mathrm{x}}=\mathrm{ac}_{\mathrm{w}}=\dot{\mathrm{V}}_{\mathrm{cw}} \\
& \alpha_{\mathrm{cw}}=\dot{\omega}_{\mathrm{cw}}
\end{aligned}
$$

Vergelykings van bewegings wat met die rolstoel se beweging op die rollers verband hou, is:

$$
\begin{aligned}
& \mathrm{F}_{\mathrm{L}}+\mathrm{F}_{\mathrm{R}}-\mathrm{m}_{\mathrm{cg}} \mathrm{g} \sin \theta=\mathrm{m}_{\mathrm{cg}} \mathrm{a}_{\mathrm{x}} \\
& \frac{\lambda_{\mathrm{s}}}{2} \mathrm{~F}_{\mathrm{L}}-\frac{\lambda_{\mathrm{s}}}{2} \mathrm{~F}_{\mathrm{R}}=\mathrm{J}_{\mathrm{cg}} \alpha_{\mathrm{cw}}
\end{aligned}
$$

Die resulterende kragte wat dan deur die linkeraandryfwiel $\mathrm{F}_{\mathrm{L}}$ en regteraandryfwiel by $\mathrm{F}_{\mathrm{R}}$ die roller-of grondkontakpunt geproduseer word, kan bepaal word uit:

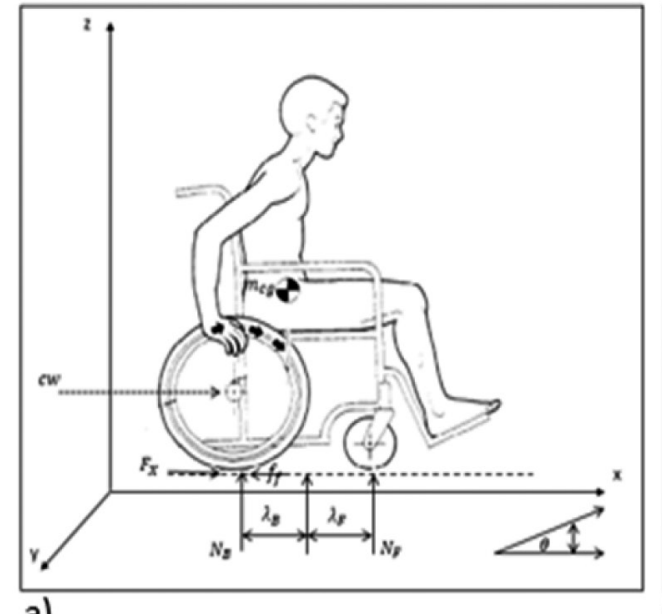

a)

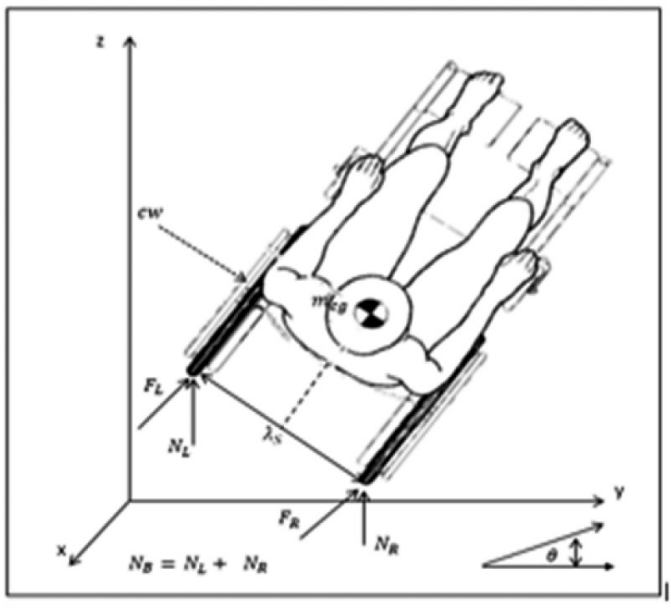

b) 


$$
\left[\begin{array}{l}
F_{L} \\
F_{R}
\end{array}\right]=\left[\begin{array}{cc}
\frac{1}{2} & \frac{1}{\lambda_{s}} \\
\frac{1}{2} & -\frac{1}{\lambda_{s}}
\end{array}\right] \cdot\left[\begin{array}{c}
m_{c g}\left(a_{x}+g \sin \theta\right) \\
J_{c g} \alpha_{c w}
\end{array}\right]
$$

Daarom,

$$
\left[\begin{array}{l}
F_{L} \\
F_{R}
\end{array}\right]=\left[\begin{array}{l}
\frac{1}{2} m_{c g}\left(a_{x}+g \sin \theta\right)+\frac{1}{\lambda_{s}} J_{c g} \alpha_{c w} \\
\frac{1}{2} m_{c g}\left(a_{x}+g \sin \theta\right)-\frac{1}{\lambda_{s}} J_{c g} \alpha_{c w}
\end{array}\right]
$$

Waar $\mathrm{F}_{\mathrm{R}}=\mathrm{F}_{\mathrm{RP}}-\mathrm{F}_{\mathrm{RBr}}$ en $\mathrm{F}_{\mathrm{L}}=\mathrm{F}_{\mathrm{LP}}-\mathrm{F}_{\mathrm{LBr}}$

$\mathrm{F}_{\mathrm{RP}}$ en $\mathrm{F}_{\mathrm{LP}}$ is onderskeidelik die regter- en linkerdryfkragte, terwyl $\mathrm{F}_{\mathrm{RBr}}$ en $\mathrm{F}_{\mathrm{LBr}}$ en onderskeidelik die regter- en linkerremkragte is.

\section{Dinamiese rolstoelmodel}

Verskeie rolstoele word as nieholonomiese meganiese stelsels beskou. Die agterwiele word onafhanklik deur die dryfaksie van die gebruiker aangedryf. Die twee voorwiele is rolwiele. Die dinamiese modelle wat in hierdie artikel gebruik word, is prakties identies aan die voorgestelde model in Siegwart en Nourbakhsh (2004) en Ghosal (2010). Hierdie model evalueer ' $n$ derde dimensie, naamlik die rolstoel op 'n helling en op 'n plat oppervlak.

Die numeriese model van die rolstoel hang af van die geometrie daarvan en van die kinematiese toestande. Die geometrie van die rolstoel is onderhewig aan die werklike ontwikkeling daarvan op die oppervlak (kyk Figuur 4), terwyl die kinematiese toestande die beweging daarvan in posisie beskryf (Siegwart en Nourbakhsh 2004).

Lagrange-formalisme (kyk vergelyking 7) is gebruik om differensiaalvergelykings af te lei wat die tydsverskuiwing van die rolstoel beskryf, maar nogtans die nieholonomiese kinematiese beperkings in ag neem (Siegwart en Nourbakhsh 2004).

$$
\begin{aligned}
& \mathcal{L}=\frac{1}{2} \mathrm{M}\left(\dot{\mathrm{x}}_{\mathrm{g}}+\dot{\mathrm{y}}_{\mathrm{g}}+\dot{\mathrm{z}}_{\mathrm{g}}\right)+\frac{1}{2} \mathrm{I}_{\mathrm{z}} \dot{\theta}^{2} \mathrm{IM} \dot{\theta} \cos \phi\left(\dot{\mathrm{x}}_{\mathrm{g}} \sin \theta-\dot{\mathrm{y}}_{\mathrm{g}} \cos \theta\right) \\
& -\mathrm{Mg} \sin \phi\left(\dot{\mathrm{x}}_{\mathrm{g}} \cos \theta+\dot{\mathrm{y}}_{\mathrm{g}} \sin \theta\right)
\end{aligned}
$$

Met inagneming van die posisie van die rolstoel in die 3D-ruimte (xyz-koördinaatstelsel) aangedui deur $q=\left(x_{g^{\prime}}\right.$ $\left.\mathrm{y}_{\mathrm{g}^{\prime}}, \mathrm{z}_{\mathrm{g}^{\prime}} \theta\right)^{\mathrm{T}}$, met $\left(\mathrm{x}_{\mathrm{g}^{\prime}} \mathrm{y}_{\mathrm{g}^{\prime}}, \mathrm{z}_{\mathrm{g}}\right)$ as die Cartesiese koördinaat die swaartepunt van die rolstoel, en met $\theta$ as die rotasiehoek van die rolstoel, word die Lagrange-funksie in die volgende vorm uitgedruk:

$$
M(q) \ddot{q}+C(q, \dot{q}) \dot{q}+G(q)=E(q) \tau+A^{T}(q) \lambda
$$

W

$$
M(q)=\left[\begin{array}{cccc}
M & 0 & 0 & \mathrm{lM} \cos \phi \sin \theta \\
0 & \mathrm{M} & 0 & -\mathrm{lM} \cos \phi \cos \theta \\
0 & 0 & \mathrm{M} & 0 \\
\mathrm{lM} \cos \phi \sin \theta & -\mathrm{lM} \cos \phi \cos \theta & 0 & \mathrm{I}_{\mathrm{z}}
\end{array}\right]
$$$$
C(q, \dot{\mathrm{q}})=\left[\begin{array}{cccc}
0 & 0 & 0 & \dot{\theta} \mathrm{l} M \cos \phi \cos \theta \\
0 & 0 & 0 & \dot{\theta} \mathrm{lM} \cos \phi \sin \theta \\
0 & 0 & 0 & 0 \\
0 & 0 & 0 & 0
\end{array}\right]
$$$$
G(q)=\left[\begin{array}{c}
M g \sin \phi \cos \theta \\
M g \sin \phi \sin \theta \\
0 \\
M g \sin \phi\left(y_{g} \cos \theta-x_{g} \sin \theta\right)
\end{array}\right]
$$$$
\mathrm{E}(\mathrm{q})_{4 \times 2}=\left[\begin{array}{cc}
\frac{\cos \theta}{\mathrm{r}} & \frac{\cos \theta}{\mathrm{r}} \\
\frac{\sin \theta}{\mathrm{r}} & \frac{\sin \theta}{\mathrm{r}} \\
0 & 0 \\
\frac{\mathrm{b}}{\mathrm{r}} & \frac{-\mathrm{b}}{\mathrm{r}}
\end{array}\right], \tau=\left[\begin{array}{l}
\tau_{\mathrm{R}} \\
\tau_{\mathrm{L}}
\end{array}\right]
$$$$
A(q)_{2 \times 4}=\left[\begin{array}{cccc}
-\cos \phi \sin \theta & \cos \phi \cos \theta & \sin \phi & -1 \\
\sin \phi \sin \theta & -\sin \phi \cos \theta & \cos \phi & 0
\end{array}\right]
$$

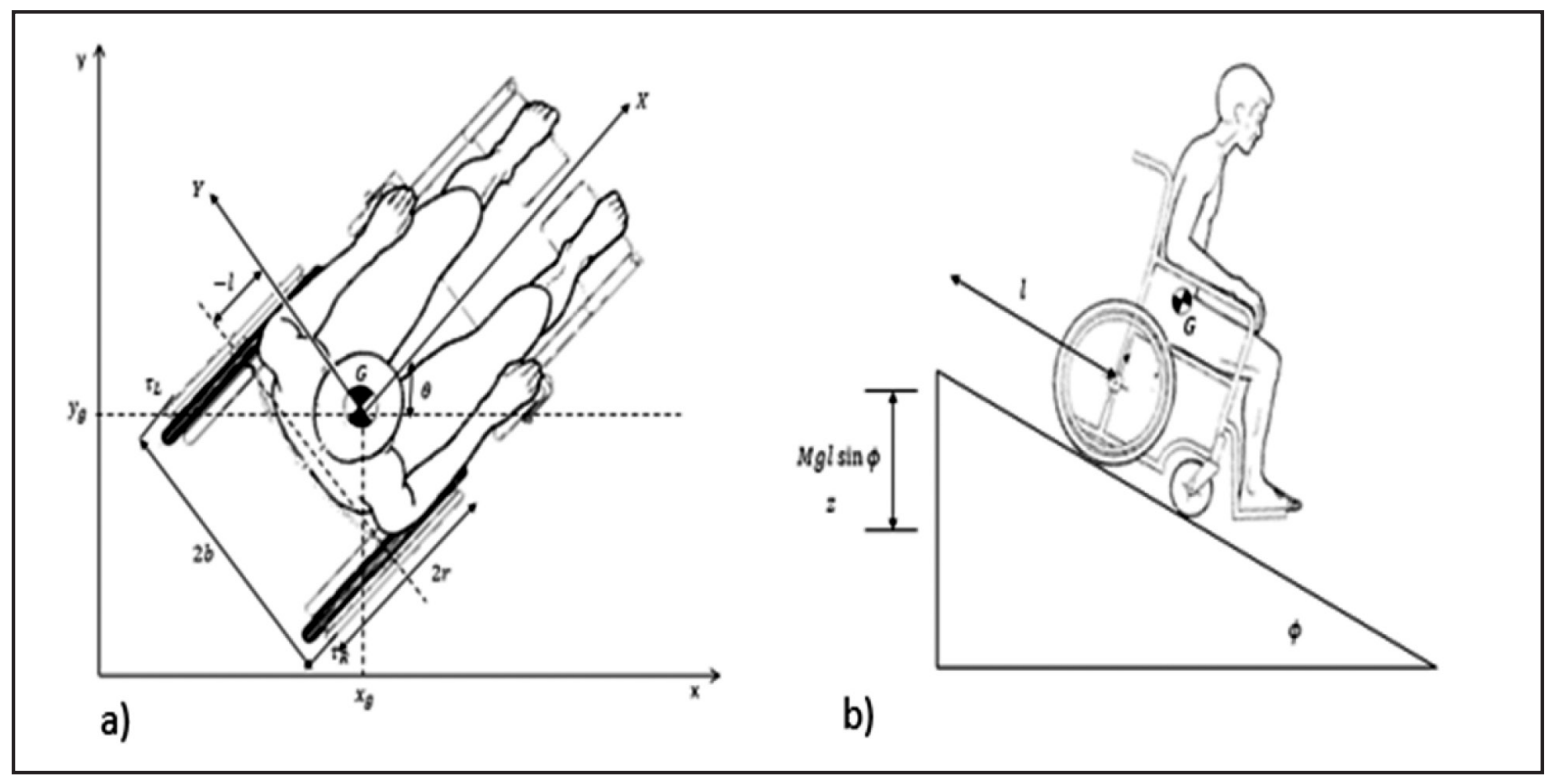

FIGUUR 4: Handgedrewe rolstoel a) op 'n plat oppervlak, en b) op 'n helling 
$\lambda$ is die vektor van Lagrange-vermenigvuldigers. Die linker- en regterwringkrag word onderskeidelik deur $T_{L}$ en $T_{R}$ aangedui. As die twee gelyk is, vind ' $n$ reglynige beweging plaas, en indien hulle nie gelyk is nie, vind ' $n$ rotasiebeweging plaas.

In die geval van die rolstoelwiele wat rol sonder om te gly, is sywaartse bewegings nie waarskynlik nie; gevolglik is die netwerk wat verband hou met die nieholonomiese beperkings loodreg op die spilpunt van die aandryfwiele, wat in toestandvorm geskryf word as $\mathrm{A}=(\mathrm{q}) \dot{\mathrm{q}}=0$ (Siegwart en Nourbakhsh 2004):

Met inagneming van $S(q) \in \mathbb{R}^{n \times m}$, 'n stel gelykmatige en lineêr onafhanklike vektorvelde wat oor die nulruimte $A(q)$ van versprei is sodat $S^{T}(q) A^{T}(q)=0$, kan die kinetiese vergelyking soos volg afgelei word:

$$
\dot{\mathrm{q}}=\mathrm{S}(\mathrm{q}) \eta
$$

Met

$$
S(q)=\left[\begin{array}{cc}
\cos \theta & -1 \cos \phi \sin \theta \\
\sin \theta & 1 \cos \phi \cos \phi \\
0 & 1 \sin \phi \\
0 & 1
\end{array}\right] \text { and } \eta=\left[\begin{array}{l}
u \\
\omega
\end{array}\right]
$$

Die snelhede $v$ en $\omega$ is onderskeidelik die lineêre en hoeksnelhede van die onderskeide punt $G$, die swaartepunt van die rolstoel en die gebruiker gekombineer.

Die afgeleide van Vergelyking 8 met betrekking tot tyd gee:

$$
\ddot{\mathrm{q}}=\dot{\mathrm{S}}(\mathrm{q}) \eta+\mathrm{S}(\mathrm{q}) \dot{\eta}
$$

Met die matriks:

$$
\dot{S}(q)=\left[\begin{array}{cc}
-\dot{\theta} \sin \theta & -\dot{\theta} \mathrm{l} \cos \phi \cos \theta \\
\dot{\theta} \cos \theta & -\dot{\theta} \mathrm{l} \cos \phi \sin \theta \\
0 & 0 \\
0 & 0
\end{array}\right]
$$

Deur vergelyking 9 en 10 in vergelyking 8 in te neem en ná vereenvoudiging, verkry ons'n meer toepaslike voorstelling van die beheerstelsel vir die dinamiese model van die rolstoel, soos volg:

$$
\begin{aligned}
& {\left[\begin{array}{c}
\dot{u} \\
\dot{\omega}
\end{array}\right]=\left[\begin{array}{c}
-\mathrm{g} \sin \theta \\
\frac{\mathrm{Mg} \sin \phi\left(\mathrm{y}_{\mathrm{g}} \cos \theta-\mathrm{x}_{\mathrm{g}} \sin \theta\right)}{\mathrm{Ml}^{2} \cos 2 \phi-\mathrm{I}_{\mathrm{z}}}
\end{array}\right]+} \\
& {\left[\begin{array}{cc}
\frac{1}{\mathrm{Mr}} & \frac{1}{\mathrm{Mr}} \\
\frac{\mathrm{b}}{\mathrm{r}\left(\mathrm{I}_{\mathrm{z}}-\mathrm{Ml}^{2} \cos 2 \phi\right)} & \frac{\mathrm{b}}{\mathrm{r}\left(\mathrm{I}_{\mathrm{z}}-\mathrm{Ml^{2 }} \cos 2 \phi\right)}
\end{array}\right]\left[\begin{array}{l}
\tau_{\mathrm{R}} \\
\tau_{\mathrm{L}}
\end{array}\right]}
\end{aligned}
$$

\section{Stelselintegrasie en hardewareontwerp}

Die stelsel wat weergegee word, is ontwerp vir twee kontroles wat op Windows-gebaseerde platforms werk wat afhanklik is van die feit dat onafhanklike ontwikkeling parallel uitgevoer kan word, en dat die virtuele wêreld (koppelvlak van die denkbeeldige omgewing met die gebruiker) as 'n afsonderlike eenheid gebruik kan word. Die integrasie in 'n enkele stelselkontroletoestel is moontlik en kan 'n oorweging wees vir die ontwikkeling van die

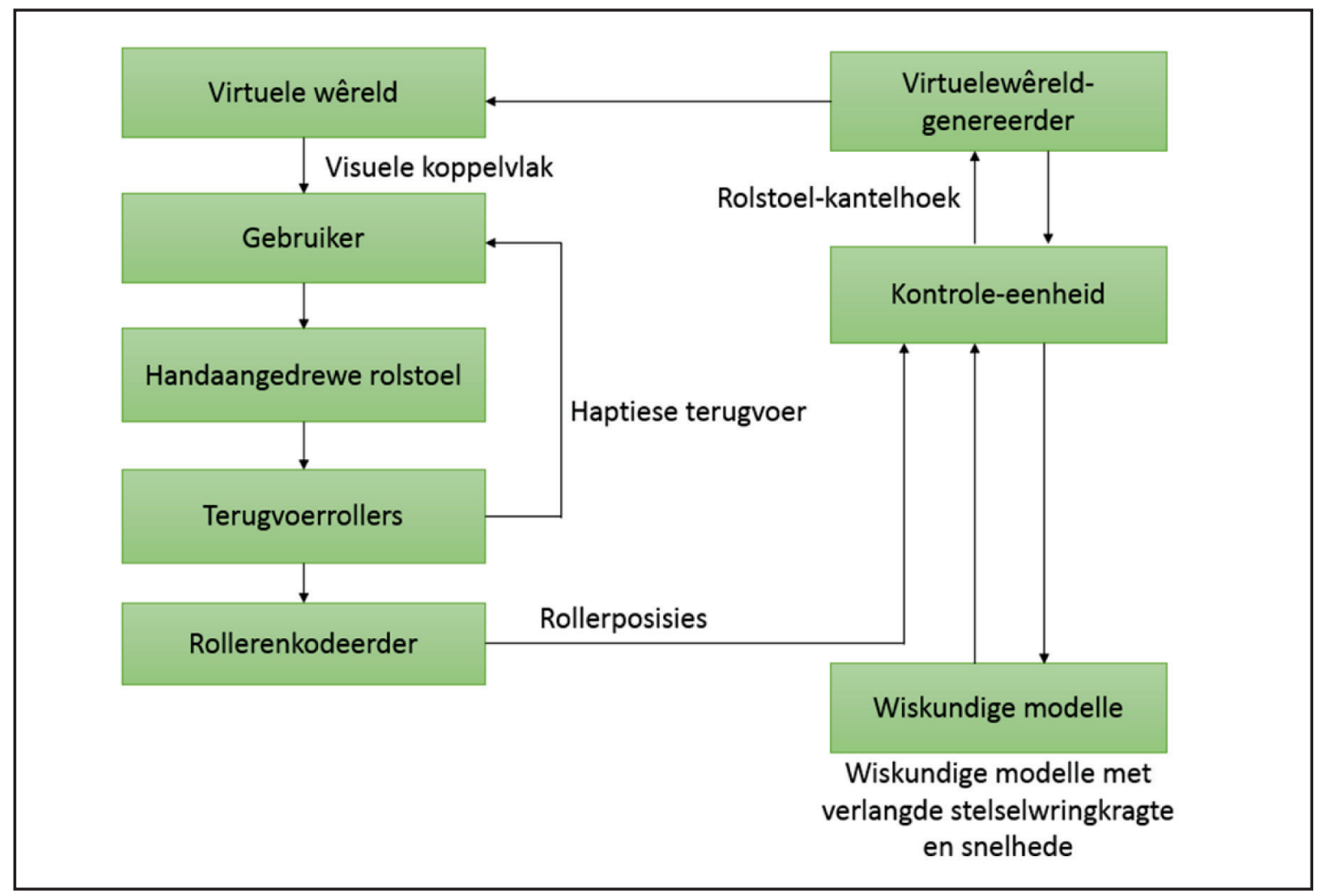

FIGUUR 5: Blokdiagram van onderlinge verbinding tussen substelsels 
volgende generasie van 'n virtuelerealiteit-bewegingsplatform in ' $n$ instaatstellende omgewing. Die onderlinge verbinding tussen al die verskillende substelsels wat met die bewegingsplatform verband hou, die rolstoel en die gebruiker word in Figuur 5 uitgebeeld. Die stelsel bestaan duidelik uit substelsels wat onderling verbind is om 'n volledige bewegingsplatform te vorm met sensors, 'n kontrole en aktueerders om visuele en fisiese terugvoer aan 'n gebruiker te voorsien. Die gebruikersaksie genereer, as gevolg van trajekbeplanning, die gewenste stelsel-instelpunt (SIP), wat die intensiteitsvlak van bewegingsterugvoer van die bewegingsplatform bepaal. Hierdie bewegingsterugvoer binne die twee grade van vryheid (2-GVV) berus op die tipe trajekte wat die gebruiker in die virtuele wêreld teëkom. Die gebruikersaksie tesame met die rolstoelsnelheid en draaiverhouding bepaal die snelhede van die aktueer- derbeweging wat binne die twee grade van vryheid (2DOF) ervaar word. In die laaste instansie bestaan die terugvoerbewegings wat deur die stelsel beheer word dus uit op- en af- en kantelbewegings van die platform, met die rolstoelwiel se rollerweerstand wat dinamiese rolstoeleienskappe in die vorm van wringkragbeheer simuleer.

\section{Ontwerp van stelselaktueerder}

Die verskillende sensors wat in die ontwerp gebruik word en hul doel bestaan hoofsaaklik uit die bepaling van rolstoel- en stelselposisies, snelhede en versnellings (Steyn et al. 2014). Die tipes sensors wat vir laasgenoemde gebruik word, is driekanaaltipe digitale pulsgenererende rotasieenkodeerders. Dit word geïnstalleer vir al die terugvoerveranderlikes wat nodig is vir beheer, soos by die aktueerderbeweging en die rolstoelbeweging.

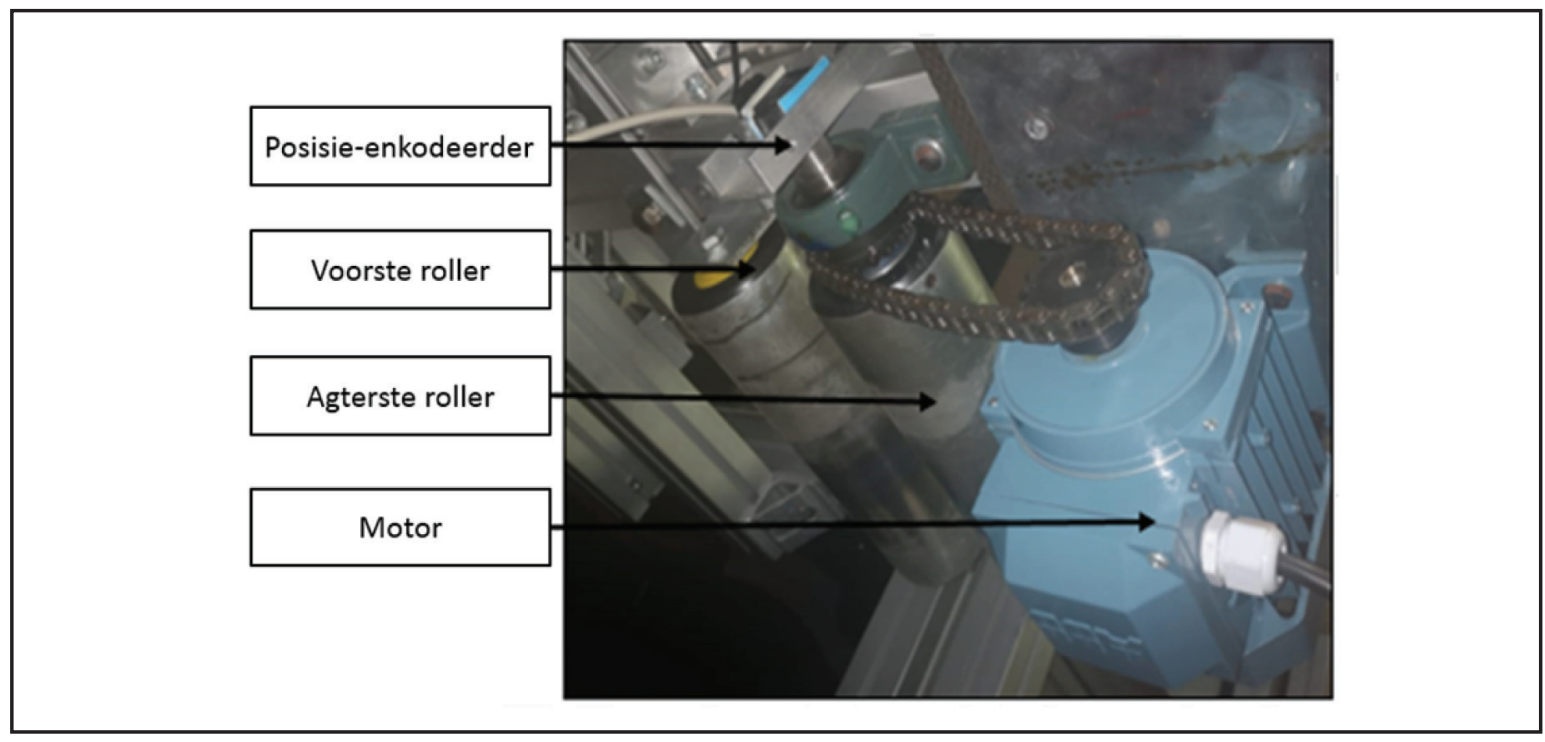

FIGUUR 6: Posisie-enkodeerder op 'n rollerpaar geïnstalleer

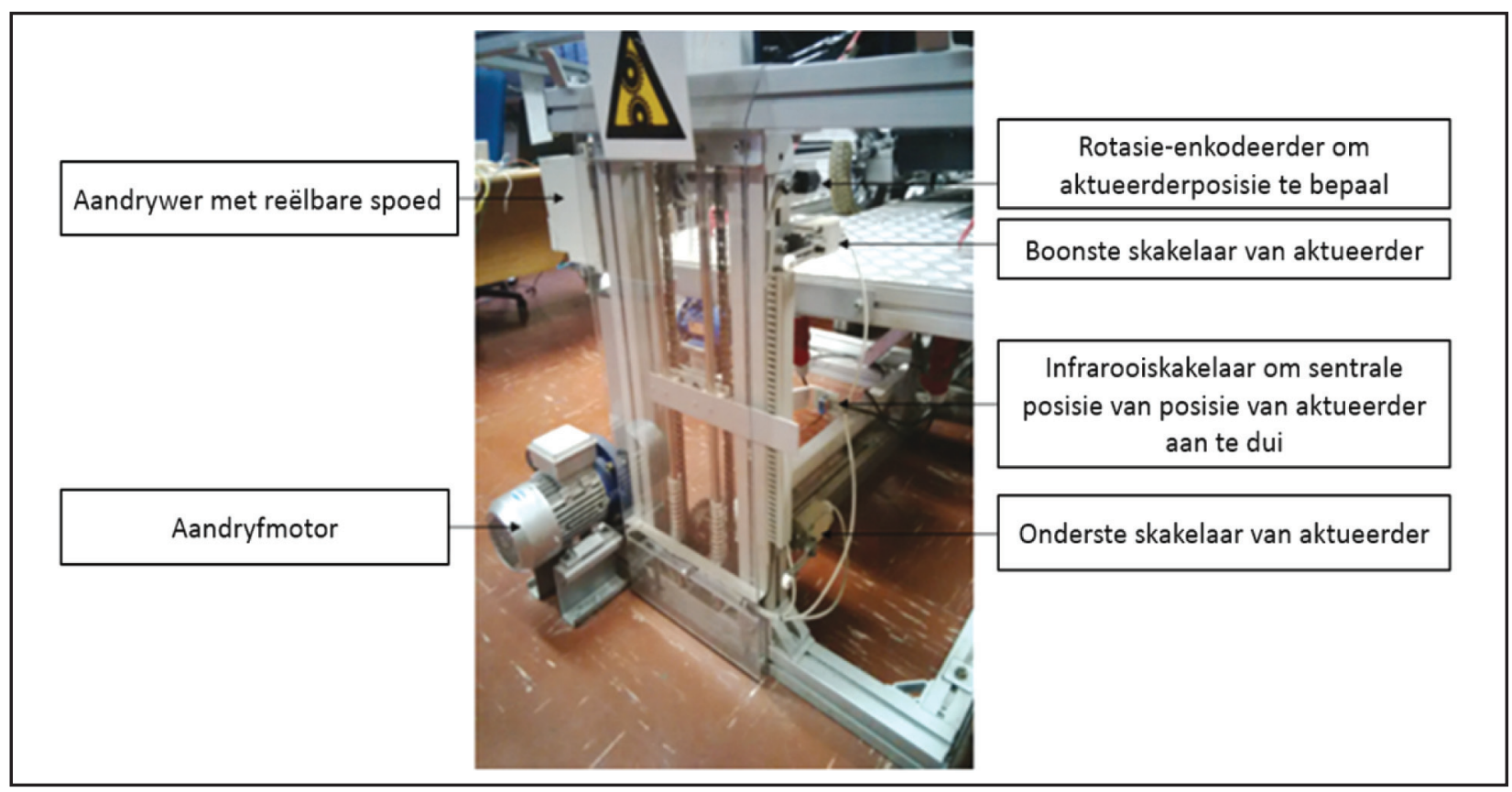

FIGUUR 7: Enkele prismatiese aktueerder se meganiese en elektriese hoofkomponente 
Die posisie-enkodeerders wat vir die rolstoel se onafhanklike aandryfwielsnelhede gebruik word, word gebruik om die beoogde pad te karteer wat in die virtuele wêreld geproduseer moet word. Die rolstoel se twee aandryfwiele word in direkte kontak met rollers geplaas om die differensiële aandrywingsbeweging te meet en die draaienkodeerders wat op elke rollerpaar gemonteer is, word in Figuur 6 uitgebeeld. Indien $\omega_{\mathrm{L}}$ en $\omega_{\mathrm{g}}$ die linker- en regterhoeksnelheid van die onderskeie aandryfwiele van die rolstoel voorstel, word vorentoe- en agtertoe-omrekenings met behulp van $\omega_{\mathrm{L}}$ en $\omega_{\mathrm{R}}$ uitgevoer. Die rotasie van die rolstoel word bewerkstellig deurdat $\omega_{\mathrm{L}}<\omega_{\mathrm{g}}$ of $\omega_{\mathrm{L}}>\omega_{\mathrm{g}}$.

Die posisie-kodeerders op die prismatiese aktueerders bepaal die lineêre posisies van aktueerderverplasing om sodoende ' $n$ beoogde beheerde posisie te bereik, om die bewegingsplatform se op- en af- en kantelaksies te simuleer. Die verskillende op- en af- en kantelaktueerdersensors vir 'n prismatiese enkelbewegingaktueerder kan in Figuur 7 gesien word. Bewegingsbeperking-skakelaars word gebruik om kritieke aktueerderperk- en nulposisies te meet. Hierdie skakelaars word op die aktueerders se lineêre omrekenings geplaas om die bewegingseindpunte te bepaal. Dié meganiese beperkingskakelaar beskerm die aktueerder daarteen om moontlik buite perke te beweeg, wat skade aan die meganiese stelsel kan veroorsaak. Infrarooi weerkaatsende sensors word gebruik om nulgraadposisies (gesentreerd) vir beide die lineêre aktueerders te bepaal. Nulposisiewaarneming word gebruik om die aktueerderposisies terug te stel om wegdrywing as gevolg van meganiese glip of elektriese seinfoute uit te skakel.

\section{Ontwerp en bespreking van stelselkontrole}

'n Lineêre kwadratiese reguleerder (LKR) is ontwerp om die op- en af- en kantel-platformdinamika te simuleer wat aan die intydse denkbeeldige omgewing gekoppel is.

TABEL 1: Veranderlikes

\begin{tabular}{c|c|c}
\hline Veranderlikes & Eenhede & Beskrywing \\
\hline$\ddot{\mathrm{x}}$ & $\mathrm{m} / \mathrm{s}^{2}$ & Longitudinale versnelling \\
\hline$\ddot{\mathrm{y}}$ & $\mathrm{m} / \mathrm{s}^{2}$ & Laterale versnelling \\
\hline$\theta$ & grade & Kantelhoek \\
\hline$\phi$ & grade & Op- of -afwaartse hoek \\
\hline $\mathrm{u}$ & $\mathrm{V}$ & Opdrag vir $\theta_{\mathrm{d}}$ en $\phi_{\mathrm{d}}$ \\
\hline $\mathrm{M}_{1,2,3}$ & - & Elektriese motor $1,2,3$ \\
\hline
\end{tabular}

Die kontroleontwerpstrategie wat op die LKR-struktuur gebaseer is, word in hierdie afdeling voorgestel. Die oogmerk van die kontroleontwerp is om 'n lineêre oordragmatriks te verkry wat die kwadratiese kostefunksie minimaliseer, wat die sporingsfout en die bewegingsplatformsimulatoruitset (aktueerders) insluit, deur die fisiese beperking van die bewegingsplatform in berekening te bring. Die voorgestelde beheerde uitset vir sporing word weergegee deur:

$$
\mathrm{y}=\left[\begin{array}{lll}
\ddot{\mathrm{x}} & \ddot{\mathrm{y}} & \theta
\end{array}\right]^{\mathrm{T}}
$$

$$
\mathrm{e} \equiv \mathrm{y}_{\mathrm{m}}-\mathrm{y}
$$

waar alle veranderlikes vanaf die bewegingsplatformsimulator gemeet word, sodanig dat die kontrolespoorfout weergegee word deur:

waar $\mathrm{y}_{\mathrm{m}}$ 'n vektor is wat die bewegingsplatformveranderlikes beperk sodat dit met die gemete veranderlikes ooreenstem. Hierdie veranderlikes word in Tabel 1 beskryf.

Om die bewegingsplatformsimulatorbeperkings en die minimalisering van die sporingsfout tussen die gesimuleerde handaangedrewe rolstoel en die eksperimentele bewegingsplatform te verseker, word die vergelyking om 'n optimale kontrolegebaseerde LKR te ontwerp, weergegee deur:

$$
J=\int_{t_{1}}^{t_{2}}\left(e^{T} Q e+u^{T} R u\right) d t
$$

waar $\mathrm{u}$ die uitset van die kontrole is wat die drie elektriese motors manipuleer, $\left[t_{1}, t_{2}\right]$ die verblyftydshorison van die bewegingsplatformsimulator is en $Q$ en $R$ die wegingsmatrikse is wat deur die voorgestelde LKR-gebaseerde bewegingsplatform weergegee word, soos skematies in figuur 8 weergegee word.

\section{Koppelvlakontwerp Haptiese terugvoer aan gebruiker}

Die traagheidsterugvoerstelsel simuleer gravitasiekragte. Dit verwys na die lineêre en rotasietraagheid wat 'n gebruiker aan beide die linker- en regter-aandryfwiele in 'n werklike omgewing sal ervaar wanneer ' $n$ rolstoel gebruik word, wat die gebruikershaptiese terugvoer sal voorstel. Hierdie haptiese terugvoer van kragte word op die rollerstelsel van die bewegingsplatform uitgeoefen, waarop die rolstoel se twee differensieel aangedrewe wiele geplaas is. Die doel van die haptiese terugvoer van kragte is om die lineêre en rotasietraagheid op die gebruiker van die handgedrewe rolstoel uit te oefen terwyl daar in 'n denkbeeldige omgewing genavigeer word. Onafhanklike teenoorgesteldekrag-terugvoer word by elke roller deur die dryfaksie van 'n gebruiker geproduseer, wat deur die dryfkragte $\mathrm{F}_{\mathrm{L}}$ en $F_{R}$ bepaal word, soos in Vergelyking 6 weergegee word.

In Figuur 9 kan die voorstelling van 'n enkele rolterugvoerstelsel waargeneem word met die rolstoel se dryfwiel by 'n snelheid van $+\omega_{w}$ en in direkte kontak met die geaktueerde kragterugvoerroller ( $r x$ ). $F_{x}$ stel 'n enkele wrywingskrag voor wat verband hou met hetsy $F_{L}$ of $F_{R}$. Die veranderlikes $\omega_{\mathrm{m}}$ en $\tau_{\mathrm{m}}$ stel die gemotoriseerde aktueerder se snelheid en geproduseerde wringkrag voor.

Die aktueerder en roller word deur 'n ketting aan 'n elektriese, gemotoriseerde aktueerder gekoppel. Die totale kettingspanning kan deur $\mathrm{T}_{\mathrm{c}}=\mathrm{T}_{\mathrm{c} 1}+\mathrm{T}_{\mathrm{c} 2}$ voorgestel word. Slegs die totale spanning $T_{-} c$ van die boonste en onderste kettings sal in aanmerking geneem word, aangesien die 


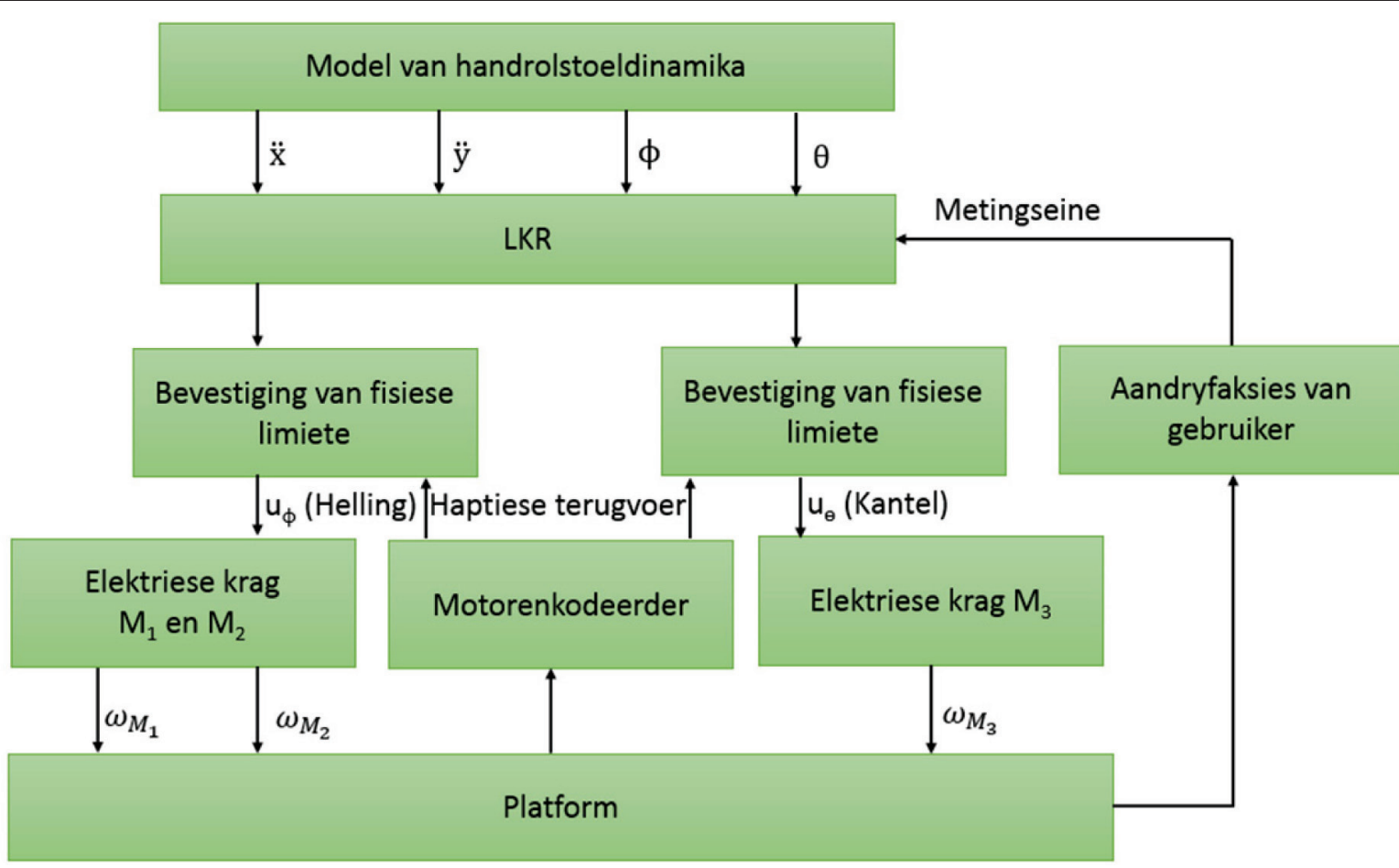

FIGUUR 8: Blokdiagram van die LKR-gebaseerde bewegingsplatform

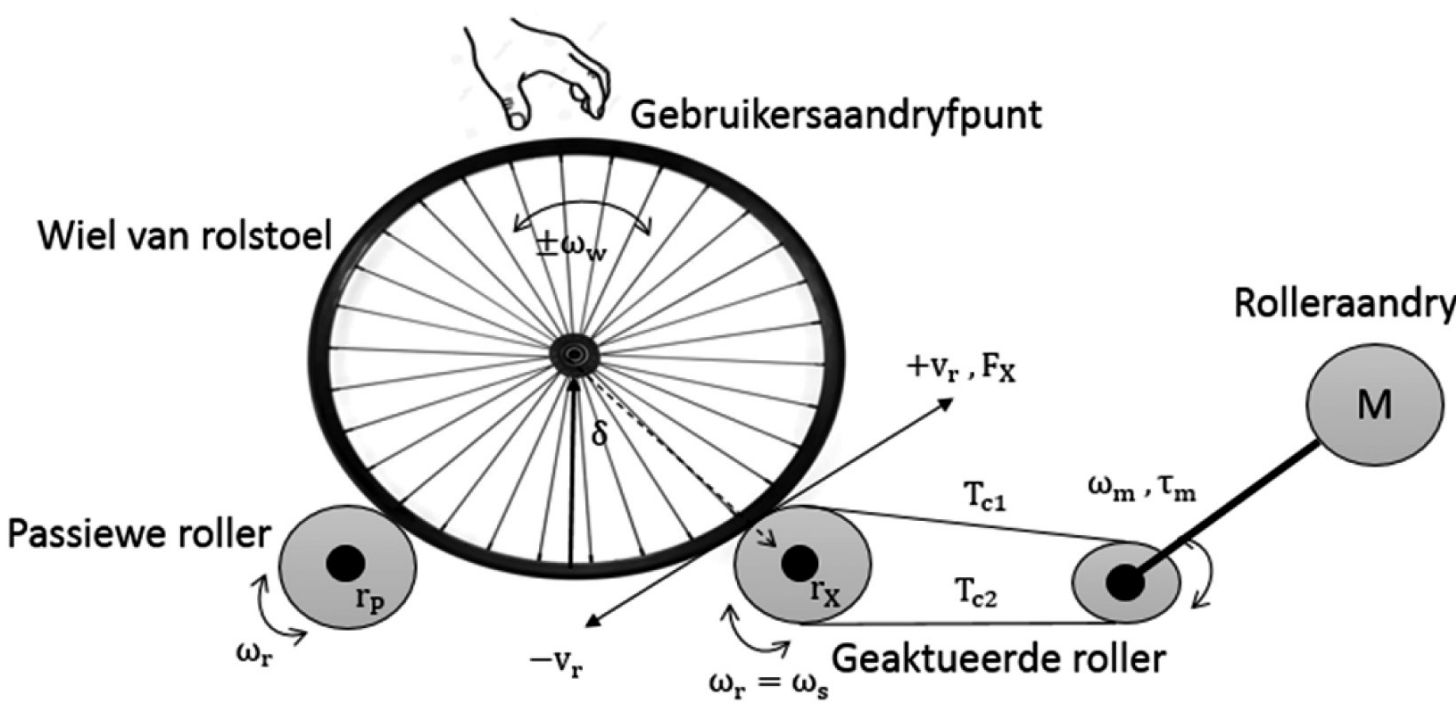

FIGUUR 9: 'n Voorstelling van 'n enkele aandryfwiel se rollerkragterugvoerstelsel

werklike spanning die voorafspannings insluit, wat nie in hierdie stelsel bepaal word nie.

Vanuit die wrywingskragte van Vergelyking 5, wat deur die linker- en regterwiele van die rolstoel se differensieel aangedrewe stelsel gegenereer word, kan die volgende vergelykings afgelei word van die hoekmomentum wat met die rollers en terugvoermotors verband hou:

$$
\begin{aligned}
& \mathrm{M}_{\mathrm{m}}-\mathrm{T}_{\mathrm{c}} \mathrm{r}_{\mathrm{m}}=\mathrm{J}_{\mathrm{m}} \alpha_{\mathrm{m}} \\
& \mathrm{T}_{\mathrm{c}} \mathrm{r}_{\mathrm{r}}=\mathrm{J}_{\mathrm{r}} \alpha_{\mathrm{r}}
\end{aligned}
$$

waar die kettingspanning $T_{c}=F_{L}$ of $F_{R}$ en $M_{m}$ en die verlangde momentum van die linker- of regtermotor is.

'n Beperking op die beweging is dat die lineêre versnelling van die ketting en die twee kettingrat-kontakpunte gelyk moet wees:

$$
\alpha_{\mathrm{r}} \mathrm{r}_{\mathrm{r}}=\alpha_{\mathrm{m}} \mathrm{r}_{\mathrm{m}}
$$

Deur Vergelyking 16 in terme van $\alpha_{\mathrm{m}}$ in Vergelyking 14 en ook Vergelyking 15 in terme van $\alpha_{\mathrm{r}}$ in Vergelyking 14 te vervang, word die verlangde wringkrag wat die linkermotor $\left(\mathrm{M}_{\mathrm{mL}}\right)$ en regtermotor $\left(\mathrm{M}_{\mathrm{mR}}\right)$ benodig om terugvoer op 
die rollers te genereer ten einde die rolstoel se traagheidskragte en swaartekrag te simuleer:

$$
\begin{aligned}
& M_{m L}=F_{L}\left(r_{m}+\frac{J_{m} r_{r}^{2}}{J_{r} r_{m}}\right) \\
& M_{m R}=F_{R}\left(r_{m}+\frac{J_{m} r_{r}^{2}}{J_{r} r_{m}}\right)
\end{aligned}
$$

met $\mathrm{J}_{\mathrm{r}}$ die rollertraagheid, en $\mathrm{J}_{\mathrm{m}}$ die traagheid van die elektriese motor, vir beide die linker- en regterterugvoermotors. Die koppeling van die motor en die ketting word bewerkstellig deur ' $n$ kettingwiel met 'n deursnee van $r_{m}$, terwyl 'n roller se deursnee gelyk is aan $r_{r}$.

\section{Visuele koppelvlak}

Die visuele koppelvlak met die gebruiker van die handgedrewe rolstoel bestaan uit 'n bewegingsplatform met vier grade van vryheid en 'n haptiese stelsel. Die platform stel gebruikers in staat om die versnellings waaraan hulle onderwerp word oor te sein as gevolg van die navigasie wat in die denkbeeldige omgewing plaasvind. Dit laat ook toe dat die verskillende hellings van die terrein van die virtuele wêreld waarbinne die gebruiker beweeg, gereproduseer word. Wat die haptiese stelsel betref, bestaan dit uit twee aktiewe rollers wat aangedryf word deur motors wat dien as koppelvlak met die handgedrewe rolstoel, wat só geposisioneer moet wees dat die wiele permanent in kontak met die rollers is. Hulle het twee funksies. Aan die een kant word die rollers geaktueer wanneer die gebruiker die handgedrewe rolstoel se wiele beweeg en neem hulle die bedoeling van die gebruiker se dryfaksie waar. Andersyds boots hulle die toestande van die oppervlak van die denkbeeldige omgewing deur die beweging van die rollers na. Met ander woorde, na gelang van die helling en oppervlak van die denkbeeldige omgewing waarin die gebruiker hom bevind, kan die gebruiker selfs gemak van beweging agterkom wanneer hy die rolstoel se wiele gebruik. Die bewegingsplatform en die aktiewe gemonteerde rollers kan in Figuur 10 gesien word. Die bewegingsplatform-beheereenheid is verantwoordelik vir die meting en verwerking van die beweging van die rollers, sowel as om die rotasie wat ooreenstem met die rotasie wat die wiele van die virtuele rolstoel ervaar op die rollers te genereer. Die kommunikasie tussen die gebruiker van die handgedrewe rolstoel op die bewegingsplatform en die virtuele wêreld vind plaas met behulp van die Labjack-toestel.

\section{Resultate}

In die voorafgaande gedeelte is die ontwerp van die differensiële aandrywing van 'n handgedrewe rolstoel en die kontroleontwerp weergegee wat die gebruiker, die handgedrewe rolstoel en die omgewingskoppelvlak met die bewegingsplatform integreer. Die fokus van hierdie afdeling is om die geïmplementeerde resultate van die gebruiker te ontleed wanneer hy hom in 'n handgedrewe rolstoel aandryf. Om 'n duidelike idee van hierdie resultate tekry, word dieblokdiagram van diestelselkontroleontwerp (kyk Figuur 11) en die voorstelling van die gebruikersnavigasie (kyk Figuur 12) uitgebeeld.

Figuur 11 toon die blokdiagram van die ontwerp van die kontrole. In hierdie figuur word die enkodeerdersein, gebruikersinvoersnelheid, geaktueerde rollersnelheid, kontrole-eenheid, rolleraktueerder en rollerenkodeerder voorgestel. Tydens die gebruikersaandryfaksie word 'n rollersnelheid geproduseer en deur die enkodeerder gemeet. Die geproduseerde rollersnelheid (enkodeerdersein) word verder deur die stelselinvoer gemeet om die graad van steilheid (gradiënt) daarvan te bepaal. Indien die rollersnelheid wat geproduseerde word positief is, is die stelsel-IP (instelpunt) die gebruikersnelheidinvoer (rollersnelheid geproduseer deur gebruikersaandryfaksie), en indien die geproduseerde rollersnelheid negatief is, sal die stelsel-IP die geaktueerde rollersnelheid wees. Die geaktueerde rollersnelheid word geproduseer deur die dinamiek van die gebruiker van die handgedrewe rolstoel wat in Vergelyking 6 weergegee word. Hierdie dinamiek hang af van die gebruikersaandryfaksie om die roller te aktueer. Die stelsel-IP (gebruikersinvoersnelheid of geaktueerde rollersnelheid) word vergelyk met die werklike rollersnelheid (gemeet deur die stelselenkodeerder), en die resulterende foutsein word in die kontrole-eenheid ingevoer. Die beheereenheid produseer 'n kontrolesein wat gebruik sal word om die rolleraktueerder tot die gewenste instelpunt te dryf. Die gewenste instelpunt is die gebruikersinvoersnelheid en die geaktueerde rollersnelheid. Die kontroleerstelselontwerp wat uitgebeeld word, kan toegepas word op die linker- en regterrollers wat met die handgedrewe rolstoel se wiele in kontak is 
om differensiële aandrywing te produseer. Hierdie differensiële aandrywing sal dan vir die gebruiker van die handgedrewe rolstoel 'n dinamiese gevoel produseer soos wat in 'n werklike omgewing ervaar sou word.

Figuur 12 beeld die differensiële gebruikersaandrywing in die denkbeeldige omgewing uit. In hierdie uitbeelding is die hoofkomponente die enkodeerderinvoersein, die kontrolestelsel, die stelselenkodeerders en die gebruikersnavigasie in die virtuele wêreld. Tydens die gebruikersaandryfaksie lees die enkodeerder die gebruikerinvoersein (gebruikersaandryfaksie). Die gebruikersinvoersein word dan vergelyk met die stelselenkodeerderseine (rolleraktueringsmeting); die resulterende sein (foutsein) word dan in die stelselkontrole in verwerk. Die stelselkontrole produseer ' $n$ gekontroleerde sein wat in die stelsel se rolleraktueerders geïntegreer sal word om die stelselrollers aan te dryf, en die stelselrollersein word dan na die gebruikersnavigasie in die denkbeeldige omgewing omskep. Die gebruikersnavigasie van die handgedrewe rolstoel kan as 'n lineêre beweging in die denkbeeldige omgewing in uitgebeeld word. Die lineêre progressie in die virtuele wêreld in word gebruik vir die gebruiker om 'n realistiese gevoel van navigasie op die handaangedrewe rolstoel te ervaar. Die geïmplementeerde resultate van hierdie beweging word in hierdie afdeling aangebied met behulp van die LKR- en PIA-kontrolestelsel.

\section{Gebruikersinvoeraandrywing}

Die resultate wat in hierdie afdeling aangebied word, is die gemete gebruikersinvoersnelheid waarteen die handgedrewe rolstoel se wiele aangedryf word, wat op die stelselrollers en enkodeerders gemonteer is. Die stelselenkodeerders is verantwoordelik vir die meting van die
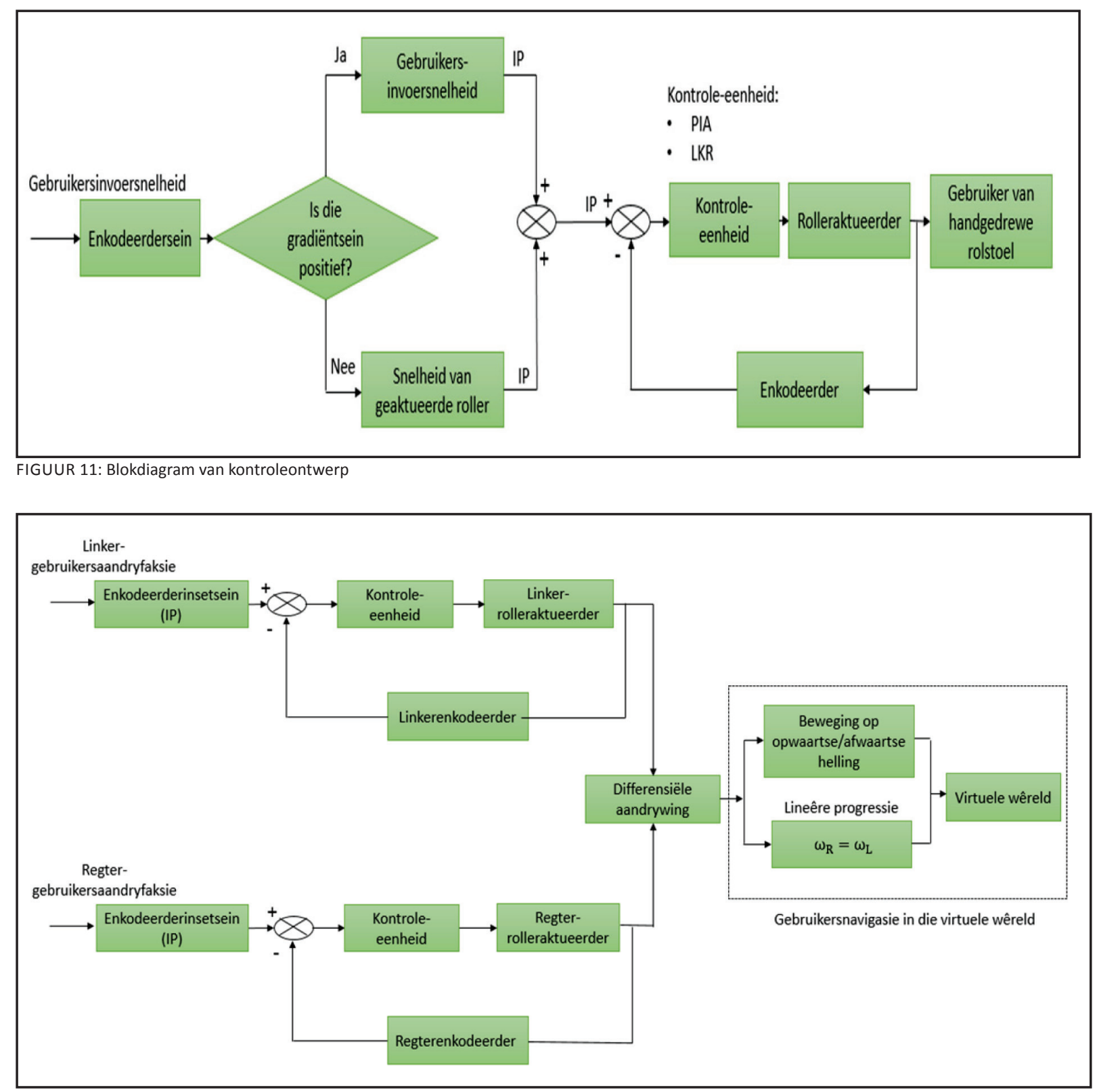

FIGUUR 12: Uitbeelding van gebruikersnavigasie 
gebruikersnelheid op die handgedrewe rolstoel. Die geproduseerde gebruikersnelheid kan gebruik word as 'n voorspelde spoed van die gebruiker van 'n handgedrewe rolstoel om 'n realistiese dinamiese sein te implementeer wat aan die stelselaktueerders gestuur word om die stelselrollers te aktueer, wat daartoe sal bydra dat die rolstoelgebruiker die navigasie in 'n denkbeeldige omgewing ervaar terwyl die gebruiker die handgedrewe rolstoel se wiele aandryf.

In Figuur 13 word die resultate weergegee van die geproduseerde gebruikersinvoersnelheid terwyl 'n dryfaksie uitgeoefen word op die wiele van die handgedrewe rolstoel wat op die stelselrollers gemonteer is. Hierdie figuur toon die gemete snelheid $(0,9 \mathrm{~m} / \mathrm{s})$ van die stelselenkodeerders wat deur die gebruiker geproduseer word deur 'n dryfkrag op die wiele van die handgedrewe stoel uit te oefen.
Figuur 14 stel die rollersnelheid en die sein van die ARS (aandrywer met reëlbare spoed) voor. Die snelheid wat voorgestel word, is 'n enkele aandryfaksie wat deur die gebruiker geproduseer word. Hierdie resultaat kan in twee dele verdeel word: die gebruikerinvoer (geproduseerde snelheid) en die vereiste ARS-sein. Die vereiste ARS-sein word gebruik om die stelselroller aan te dryf sodat ' $n$ dinamiese gevoel geproduseer word soos in 'n werklike omgewing ervaar sou word. Hierdie dinamiese gevoel kan op die linker- en regterrollers ervaar word.

Figuur 15 illustreer die gebruikersaandryfaksie van 'n handgedrewe rolstoel; hierdie figuur toon die resultaat wat in figuur 14 verkry is. Soos in figuur 14 getoon word, word die rollersnelheidgradiënt (gebruikersinvoersnelheidgradiënt) negatief nadat die gebruiker 'n dryfaksie uitoefen het, en dan word die roller geaktueer om ' $n$ dinamiese gevoel na te boots soos wat in 'n werklike omgewing ervaar sou word.

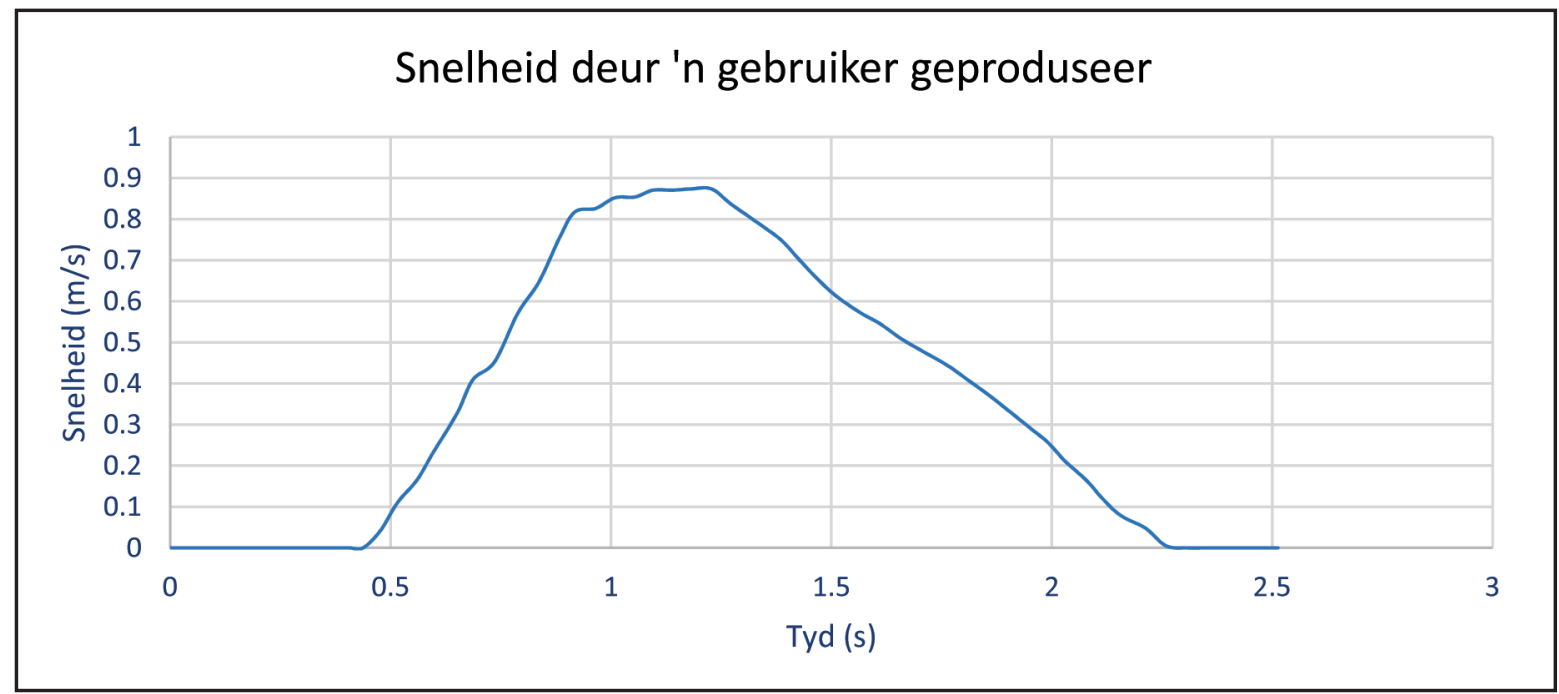

FIGUUR 13: Sein van gebruikersaandryfaksie

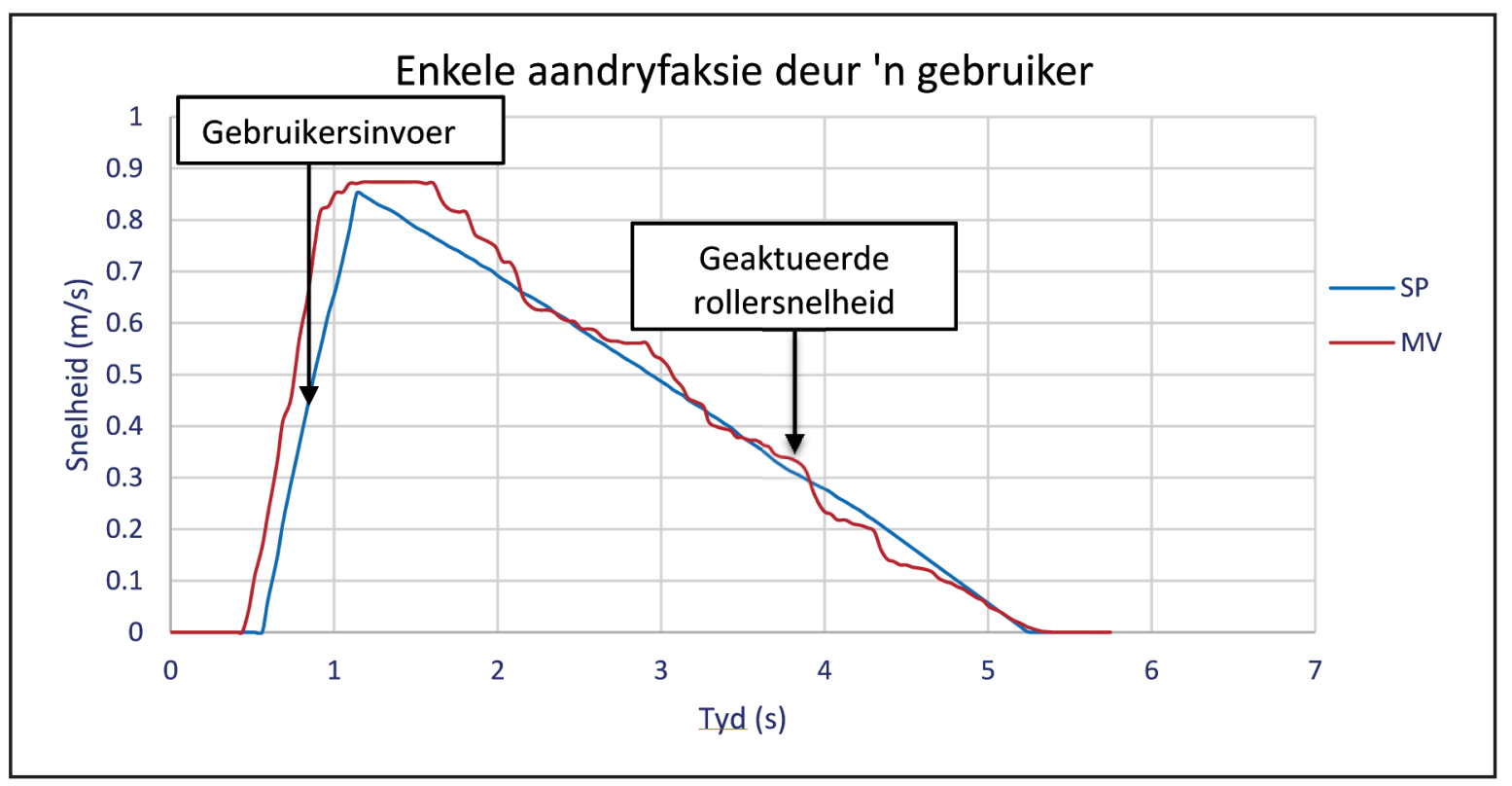

FIGUUR 14: Geïmplementeerde respons op 'n enkelspoedoprit 


\section{Stelselgeïmplementeerde resultate}

In hierdie afdeling kan die opritsein voorgestel word as 'n gebruikersaandryfaksie (gebruikersnelheidsinvoer) op 'n handgedrewe rolstoel wat op die stelselrollerenkodeerders gemonteer is. Die seine van die stelselrollerenkodeerders word in afdeling 4.1 voorgestel. Tydens die gebruikersnavigasie (gebruikersaandryfaksie) word die rolleraktueerderseine deur die stelselenkodeerder gemeet en word die seinverskille (foutsein) tussen die gebruikersaandryfaksie en die gemete rolleraktueerder in die stelselkontrole ingevoer. Die foutsein word dan verwerk deur die stelselkontrole, wat ' $n$ beheerde sein (gemanipuleerde veranderlike) geproduseer het. Die werklike gemanipuleerde veranderlike $(\mathrm{GV})$ in die daaropvolgende figure in hierdie afdeling verteenwoordig die werklike resultate wat verkry is deur die PIA- en LKR-ontwerp te implementeer.

\section{PIA-stap- en oprit-respons}

Figuur 16 stel die werklike resultate van die stelselstaprespons van die PIA-kontrole voor. In hierdie figuur word die stapseine $(0,5 \mathrm{~m} / \mathrm{s}, 0,7 \mathrm{~m} / \mathrm{s}$ en $1 \mathrm{~m} / \mathrm{s})$ gebruik om die stelselgedrag (stelselrespons) met behulp van die PIAkontrole te ondersoek. Volgens die resultate wat in Figuur 16 verkry word, volg die gemanipuleerde veranderlike (GV) van die stelsel-instelselpunt (SP) suksesvol.

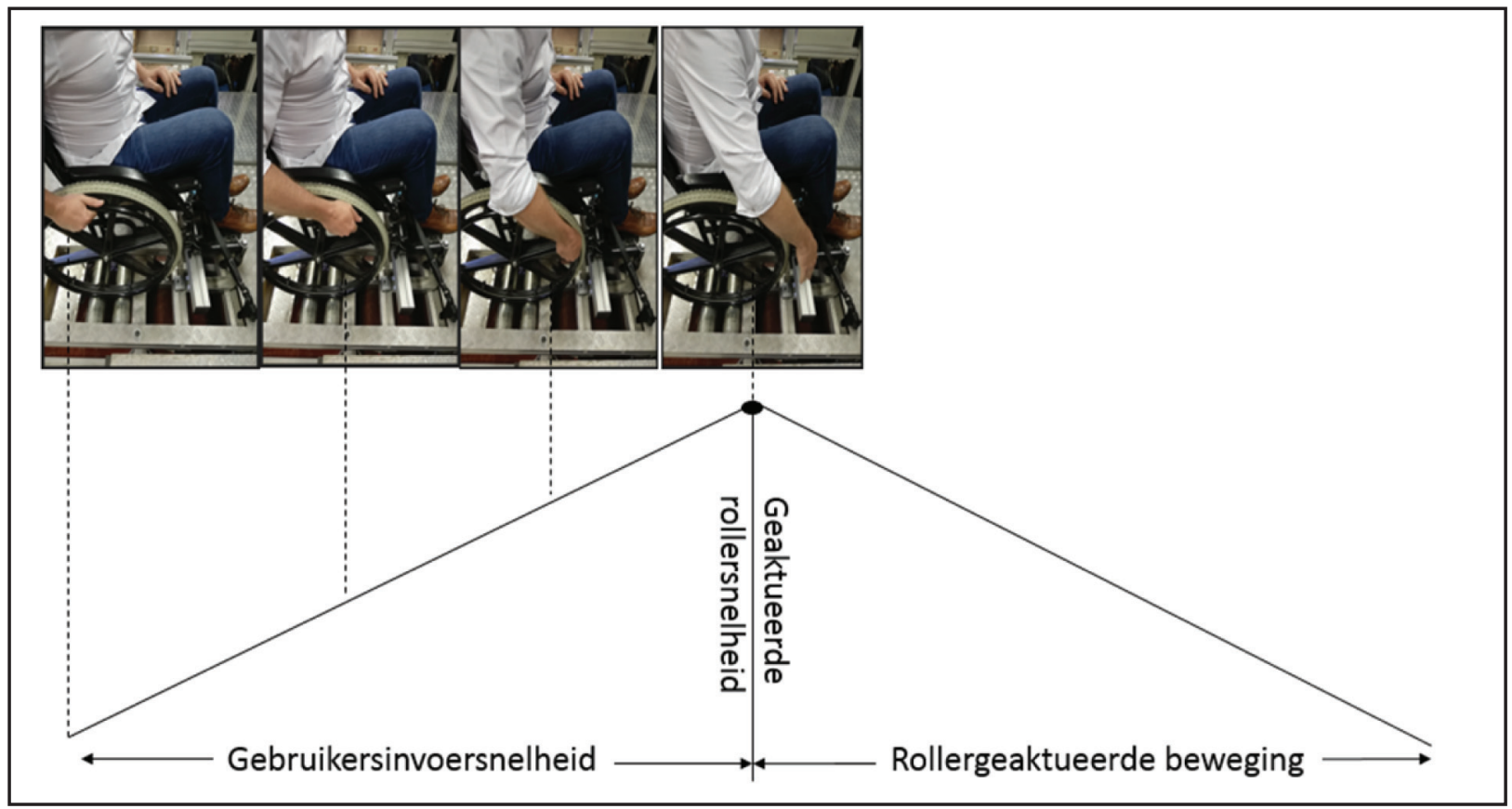

FIGUUR 15: Illustrasie van die gebruikersaandryfaksie van 'n handgedrewe rolstoel

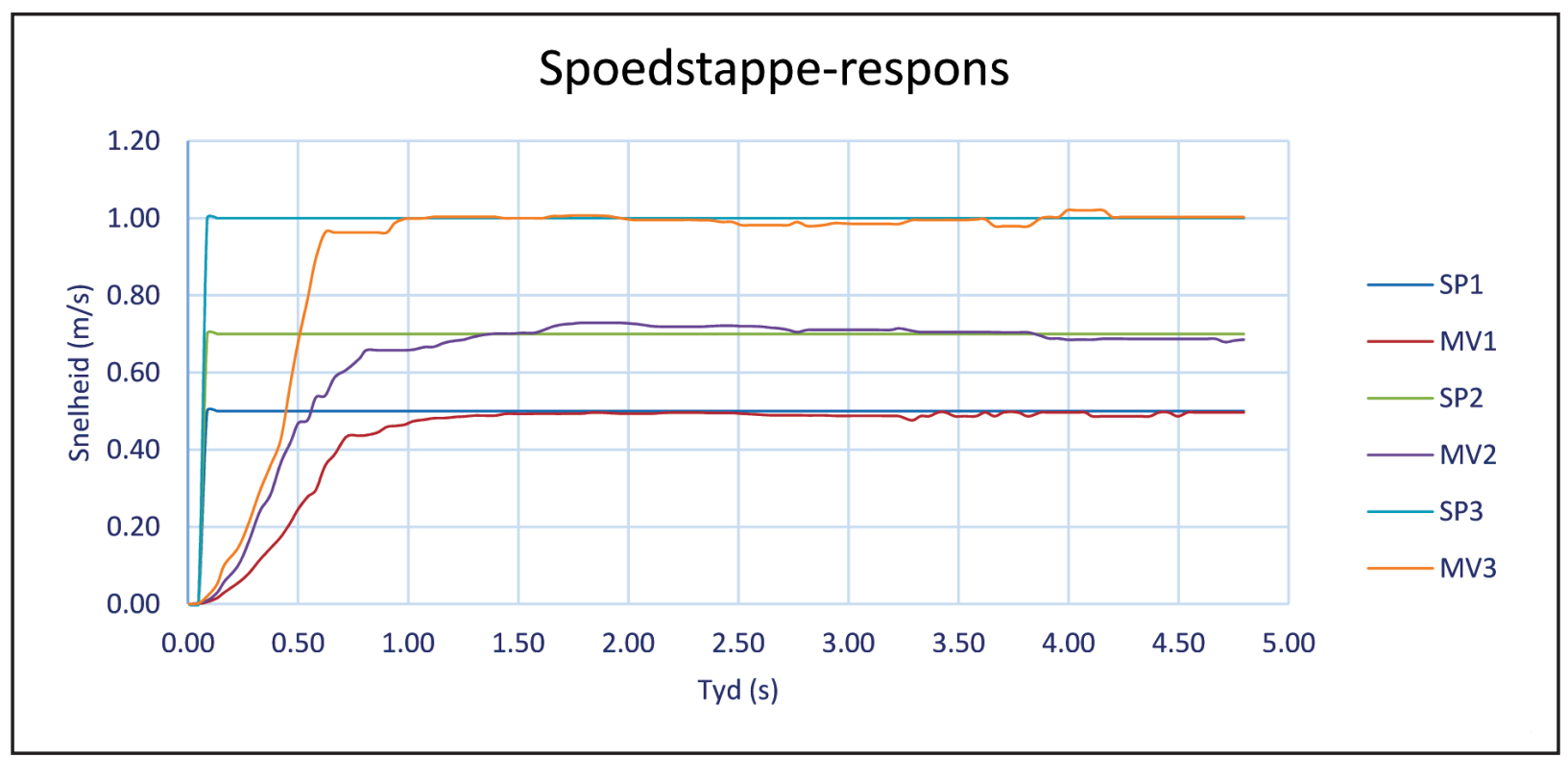

Figuur 16: Geïmplementeerde spoedstappe-respons van die PIA-kontrole 
Figuur 17 toon die werklike resultate van die stelsel se geruikersaandryfaksierespons (gebruikersnelheidinvoerrespons) van die PIA-kontrole. Die gebruikersaandryfaksie word uitgeoefen op die handgedrewe rolstoel se wiele wat op die stelselrollerenkodeerders gemonteer is en wat sodoende 'n snelheid by die stelselrollers produseer, soos in afdeling 4.1 bespreek is. Die snelheid van die stelselrollers is die werklike gebruikerinvoer en word weergegee as 'n instelpunt (IP). Die kontrole sal dan hierdie instelpunt gebruik om 'n beheerde sein (GV) te produseer wat die gebruikerinvoer (opritinvoer) navolg soos in Figuur 17 aangetoon word. In hierdie resultaat is drie gebruikersnelheidinvoerresponse geïmplementeer.

\section{LKR-stap- en oprit-respons}

Figuur 18 stel die werklike resultate voor van die stelselstapreaksie van die LKR-kontrole. Hierdie figuur toon die snelheidseine $(0,5 \mathrm{~m} / \mathrm{s}, 0,7 \mathrm{~m} / \mathrm{s}$ en $1 \mathrm{~m} / \mathrm{s})$ wat deur 'n stapinvoer gegenereer word om die stelselrespons met behulp van die LKR-kontrole te bepaal. Soos in Figuur 18 aangetoon word, het die stelsel suksesvol op die stapinvoer gereageer.

Figuur 19 beeld die gebruikersaandryfaksierespons (gegenereerdegebruikersnelhede-respons) met gebruik van die LKR-kontrole uit. In die volgende figuur word die resultaat van die prestasie van die LKR en die PIA uitgebeeld.

Figuur 20 is ' $n$ voorstelling van die stelselprestasie van die LKR- en PIA-kontrole deur die wringkrag van die stelselrollers te meet terwyl die gebruiker 'n dryfaksie op die rolstoelwiele uitoefen. Hierdie figuur toon duidelik dat die LKR-kontrole ' $n$ beter prestasie lewer vergeleke met die PIA-kontrole.

Die resultate wat in Figuur 17 en 19 weergegee word, stel die beheerde sein voor wat in die stelselrolleraktueerders geïntegreer word om die gebruikersbeweging van die

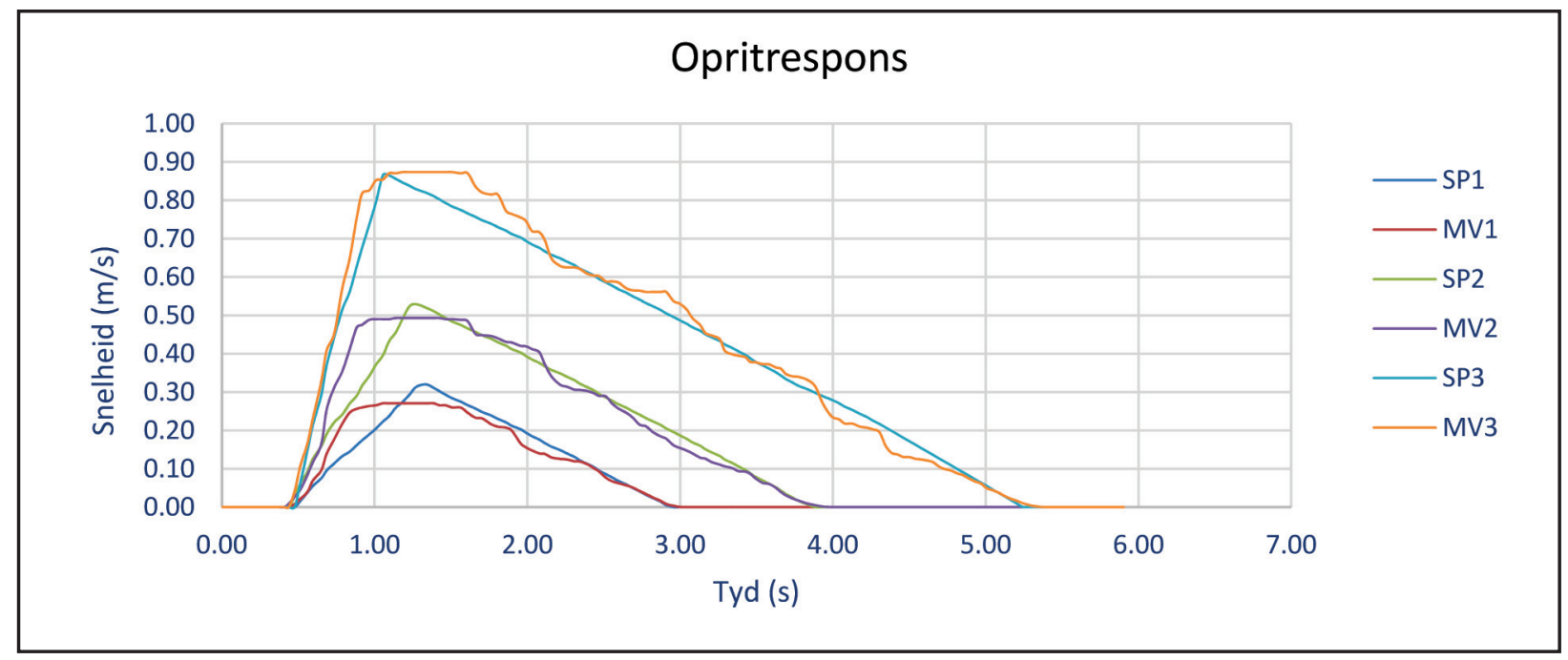

FIGUUR 17: Geïmplementeerde spoed-opritrespons van die PIA-kontrole

\section{Spoedstappe-respons}

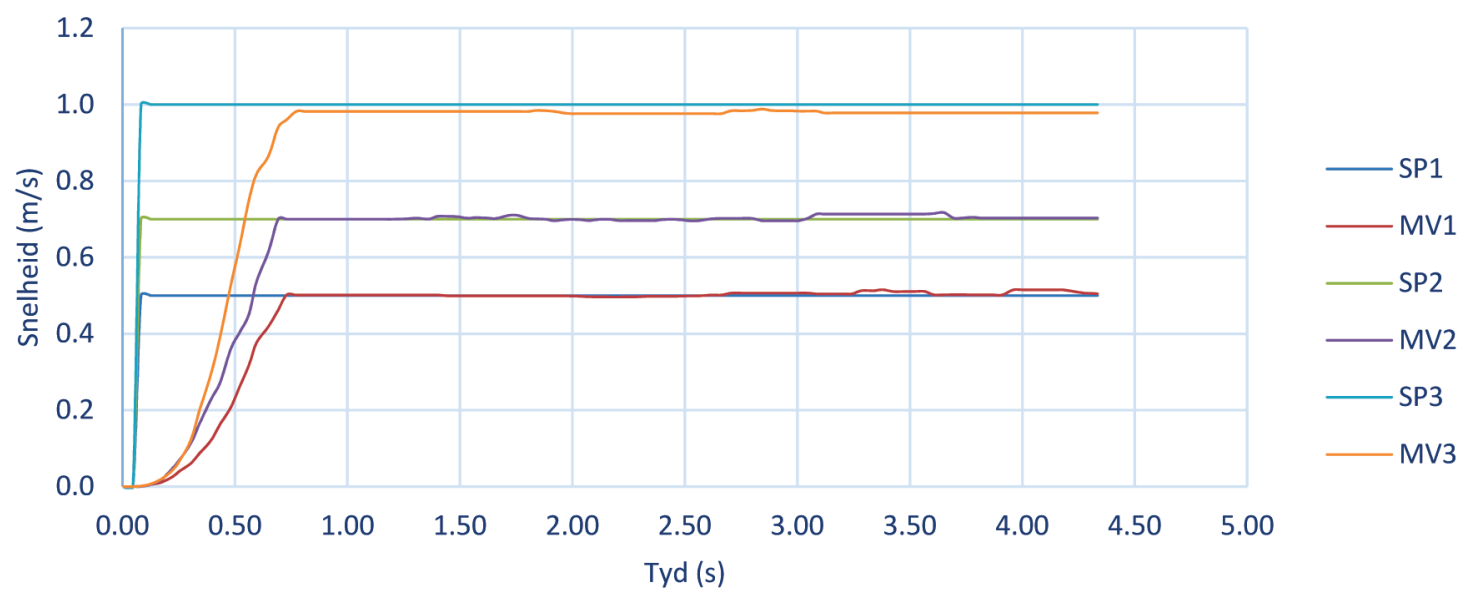




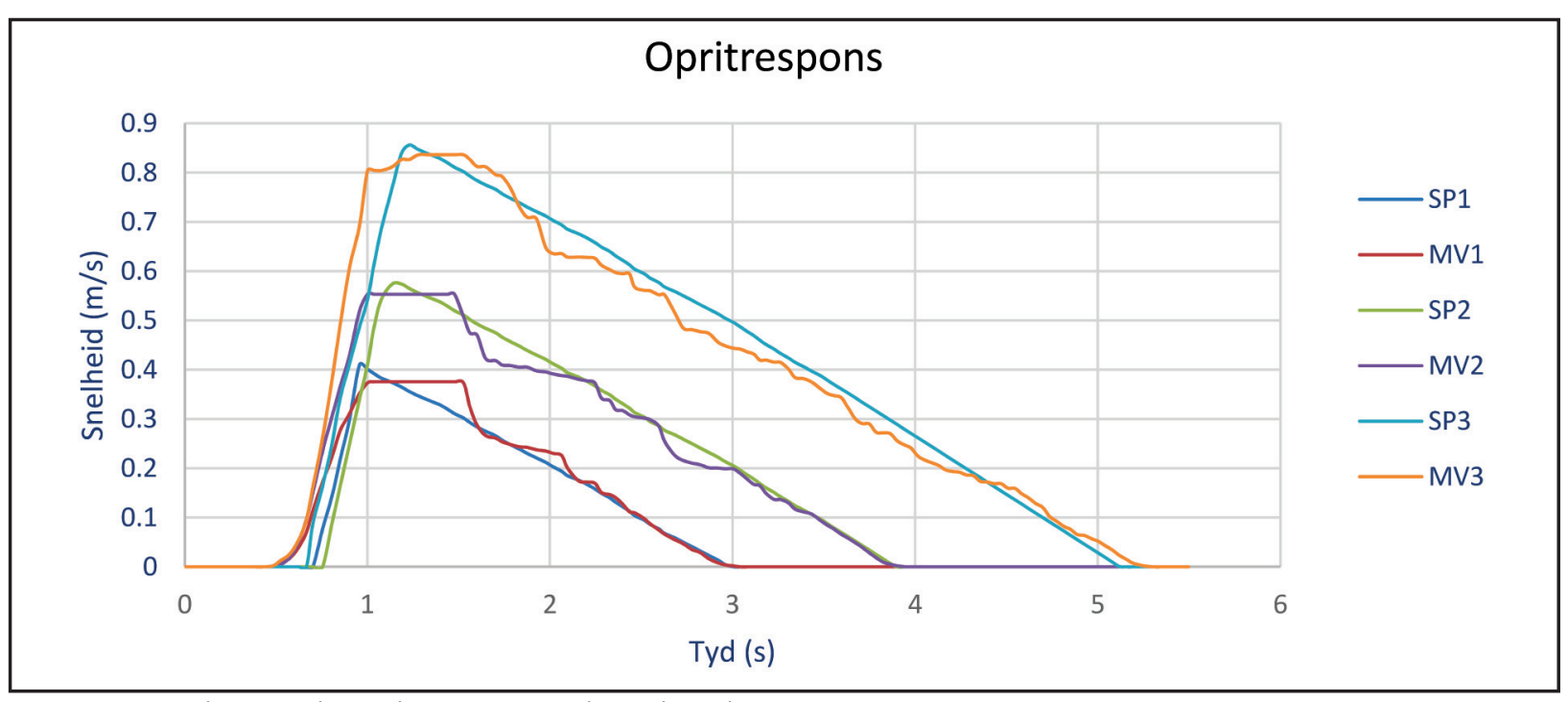

FIGUUR 19: Geïmplementeerde spoedopritrespons van die LKR-kontrole

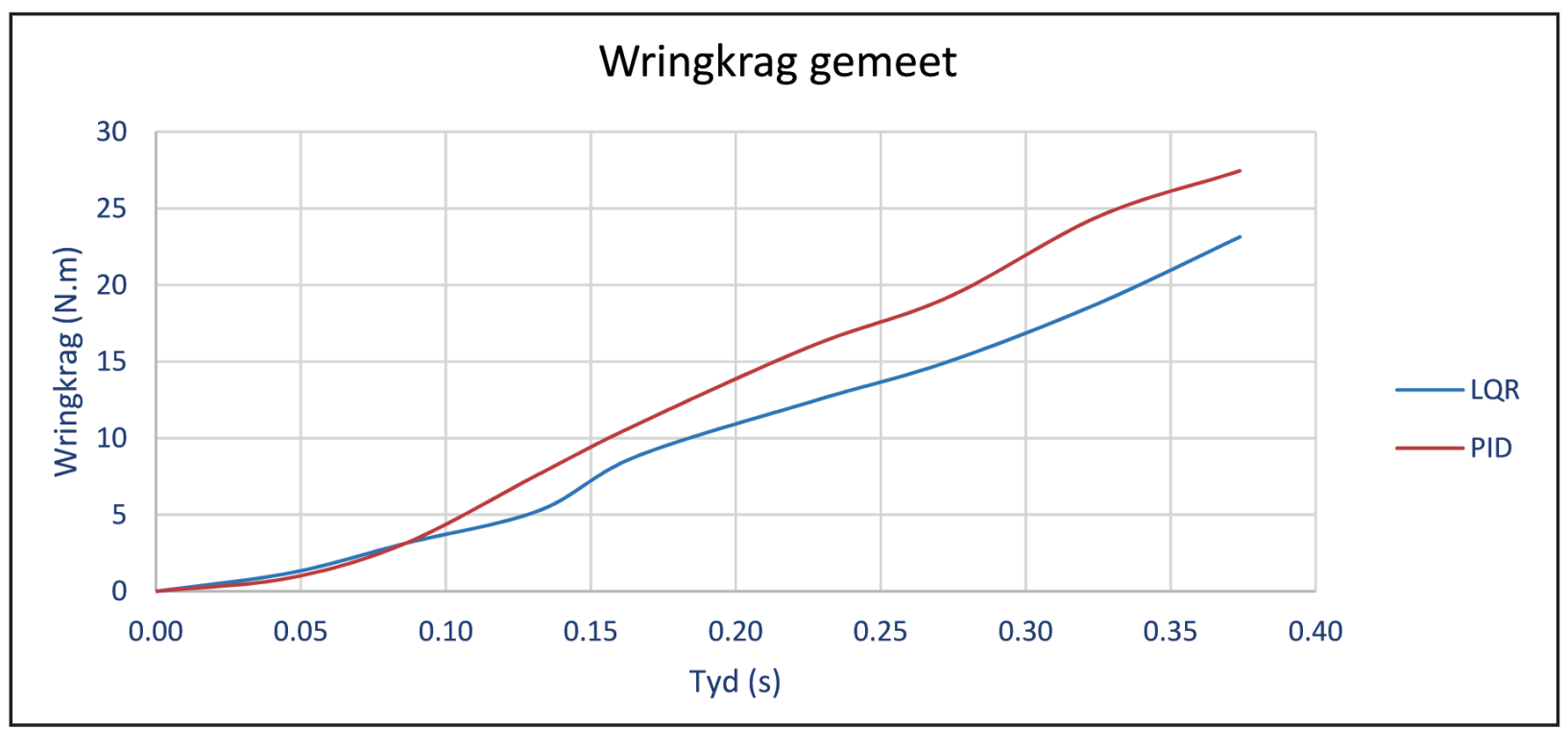

FIGUUR 20: Stelselprestasie van die LKR- en PIA-kontrole

handgedrewe rolstoel te bepaal (lineêre progressie en die beweging teen 'n opwaartse en afwaartse helling) deur die stelselrollers te aktueer. Die rolleraktuering word dan na die virtuele omgewing omskep sodat die gebruiker realistiese navigasie ervaar terwyl hy in die handgedrewe rolstoel sit.

\section{Ten slotte}

In hierdie artikel was die hoofoogmerk om 'n dinamiese model van haptiese terugvoer by 'n handgedrewe rolstoel vir ' $n$ bewegingsplatform met twee grade van vryheid (2GVV) te ontwikkel wat in 'n geougmenteerderealiteitomgewing vir die gebruik van handgedrewe rolstoele aangewend word. Dit dien as motivering om gestremdes te help oplei om rolstoele te gebruik.

Die ander deel van hierdie artikel was daarop gemik om die rollers vir die terugvoer van die handgedrewe rolstoel se wiele tydens die gebruikersaandryfaksie te modelleer en te beheer.

Die dinamiese model van die bewegingsplatform met twee grade van vryheid (2-GVV) en die haptiese terugvoer is die belangrikste bydraes van hierdie werk.

Die kontrole vir die roller is ook ontwikkel. Die kontrole is gebaseer op PIA en LKR. Die geïmplementeerde resultate het gedemonstreer dat die LKR-resultate stabiel was.

\section{Erkennings}

Eerste en die belangrikste, my opregte dank en waardering aan my studieleiers, dr Nico Steyn en prof. Karim Djouani, vir hulle geduld, asook al die leiding en ondersteuning wat hulle aan my verleen het. Ek bedank ook prof. Anish Kurien vir al die administratiewe steun wat ek ontvang het. 
Ek bedank graag in die besonder dr Nico Steyn vir sy ondersteuning, geduld en leiding; hy was vir my 'n groot bron van inspirasie om met my studies voort te gaan.

\section{Bronne van befondsing}

Baie dankie aan die Tshwane Universiteit vir Tegnologie (TUT), die Frans-Suid-Afrikaanse Instituut vir Tegnologie (F'SATI) en die Nasionale Navorsingstigting (NRF) vir die voorsiening van finansiële steun en navorsingsmateriaal wat die gladde verloop van hierdie werk moontlik gemaak het (NRF Toekenning Nommer: 90604).

\section{Bydrae deur elk van die outeurs}

Nico Steyn het die navorsingsprojekidee soos voorgehou is, gekonseptualiseer. Franck Boukila het die navorsingsteorie ontwikkel en die berekeninge uitgevoer. Nico Steyn en Karim Djouani het die analitiese metodes wat in die navorsing gebruik is, geverifieer en die bevindinge van hierdie vaktydskrifartikel gekontroleer.

\section{Bronne}

Alma, S.M., David, J. 2002. Virtual real-augmented rehabilitation for patient following stock, International Conference on Disability, Virtual Reality and Associated Technologies (ICDVRAT), ESBJEG. 82(1), pp. 898-915. https://doi. org/10.1093/ptj/82.9.898.
Anna, D. 2017. https://teslasuit.io/blog/haptic_feedback/ [Accessed 02 July 2018].

Apoora, B., Anunary, R. 2016. Human Computer Interface-Augmented Reality, International Journal of Engineering Science and Computing, 6 (1), pp. 25952595.

Calle, T., Ueda, J., Springle, S., Ferri, A. 2014. Development of a Control System to Determine Influence of Rolling Resistance in Manual Wheelchair Dynamics and Mechanical Efficiency Georgia Institute of Technology, Journal of Rehabilitation and Development, 31 (2), pp. 45-66.

Ghosal, A. 2010. Robotics: Fundamental concepts and analysis, Journal of Rehabilitation and Development New Delhi, India.

Marxent. 2015. https://www.marxentlabs.com/what-is-virtual-reality/ [Accessed 02 July 2018]

Onyango, O., Daachi, B., Hamam, Y., Djouani, K. 2018. Behaviour Modelling and System Control with Human in the Loop, Simulation Modelling Practice and Theory.

Sabatini, A.M. 2002. A Mobility Aid for the Support to Walking and Object Transportation of People with Motor Impairment, Journal of Rehabilitation and Development, Lausanne, Switzerland.

Siegwart, R., Nourbakhsh, I. 2004. Autonomous Mobile Robots, 2nd Edition, Massachusetts: The MIT Press.

Smit, P.E. 2010. Development of a 3-DOF Motion Simulator Platform Master of Science in Engineering, Stellenbosch University.

Steyn, N., Hamam, Y., Monacelli, E., Djouani, K. 2014. 'Modelling and design of an augmented reality differential drive mobility aid in an enabled environment, Simulation Modelling Practice and Theory, Elsevier. https://doi.org/10.1016/j. simpat.2014.11.006

Stroke Sleeve Spatially Distributed Tactile Feedback for Stroke Rehabilitation, http://haptics.seas.upenn.edu/index.php/Research/TactileFeedbackFor Rehabilitation. [Accessed 11 October 2018].

The Virtual Reality Training Facility, https://eng.sheba.co.il/virtual_reality_training_ facility [Accessed 11 October 2018]. 